\title{
LICENCIAMENTO AMBIENTAL NO ATUAL MODELO ENERGÉTICO: O CASO DAS BARRAGENS NO RIO MADEIRA
}

\section{LICENCIA AMBIENTAL EN EL MODELO DE ENERGÍA ACTUAL: EL CASO DE LAS PRESAS DEL RÍO MADEIRA}

Bruna Balbi Gonçalves ${ }^{1}$

Juliana de Oliveira Sales ${ }^{2}$

\begin{abstract}
RESUMO: O presente artigo tem como objetivo compreender o contexto em que está inserido o planejamento das barragens no rio Madeira, para entăo analisar o processo de licenciamento ambiental que conduziu à sua construçăo. Érealizado um resgate histórico do setor elétrico brasileiro, desde o início do processo de industrializaçăo, passando pelas privatizaçóes que reestruturaram o setor na década de 1990, pelo momento de incursăo de empresas transnacionais subsidiadas com financiamento público, até o recente rompimento democrático, que aprofunda as medidas neoliberais nesse e nos demais setores. Este resgate é fundamental para compreender como está estruturado o modelo energético em curso no país, construído por e para o mercado. Analisa-se o avanço da fronteira elétrica para a Amazônia e como seus rios estăo diretamente ligados ao desenvolvimento capitalista mundial. A partir dessa introduçăo no tema da energia, é possível vislumbrar o planejamento e construçâo das barragens no rio Madeira, desde a realizaçăo dos primeiros inventários até o desenrolar do processo de licenciamento ambiental. A análise do licenciamento, sua previsâo normativa e consecuçâo prática sâo indispensáveis para compreender o que vem dando errado na implantaçăo de grandes obras na Amazônia. As gentes e a natureza săo consideradas em confluência e os povos enquanto sujeitos políticos nesse processo de violaçóes de direitos, mas também de insurgências socioambientais.
\end{abstract}

Palavras-chave: Amazônia. Direito Socioambiental. Energia. Hidrelétricas. Natureza.

RESUMEN: Este artículo tiene como objetivo comprender el contexto en el que se inserta la planificación de las represas en el río Madeira, y luego analizar el proceso de licencia ambiental que condujo a su construcción. Se lleva a cabo un rescate histórico del sector eléctrico brasileño, desde el comienzo del proceso de industrialización, a través de las privatizaciones que reestructuraron el sector en la década de 1990, desde el momento de la incursión de empresas transnacionales subsidiadas públicamente, hasta la reciente profundización de la crisis democrática. medidas neoliberales en este y otros

1 Mestra e Doutoranda em Direito Socioambiental na Pontifícia Universidade Católica do Paraná. bruna. balbi@gmail.com

2 Mestra em Meio Ambiente e Desenvolvimento pela UFPR e Doutoranda em Direito Socioambiental na Pontifícia Universidade Católica do Paraná. julianadeosales@gmail.com 
sectores. Este rescate es fundamental para comprender cómo se estructura el modelo energético actual en el país, construido por y para el mercado. Analiza el avance de la frontera eléctrica hacia la Amazonía y cómo sus ríos están directamente vinculados al desarrollo capitalista mundial. A partir de esta introducción sobre el tema de la energía, es posible vislumbrar la planificación y construcción de las represas en el río Madeira, desde los primeros inventarios hasta el desarrollo del proceso de licencia ambiental. El análisis de licencias, el pronóstico normativo y los logros prácticos son indispensables para comprender lo que ha ido mal en la implementación de obras importantes en la Amazonía. Las personas y la naturaleza se consideran confluentes y los pueblos son sujetos políticos en este proceso de violaciones de derechos, pero también de insurgencias sociales y ambientales.

Palabras clave: Amazonía. Derecho Socioambiental. Energía. Hidroeléctricas. Naturaleza.

\section{INTRODUÇĂO}

Este artigo discorre, de forma central, sobre o ciclo de exploraçăo da mercadoria energia. Em específico, tratará de compreender o contexto de construçăo das barragens no Rio Madeira e analisará o processo de licenciamento ambiental do complexo hidrelétrico que se desenhou na regiăo, com suas duas mega hidrelétricas: Santo Antônio e Jirau.

Em um primeiro momento, consubstanciado no capítulo inicial, busca-se compreender o modelo energético em curso no país, pautado por e para as demandas do mercado. Dessa maneira, faz-se um resgate do histórico do setor elétrico brasileiro, desde o início do processo de industrializaçăo, colocando ênfase no período de privatizaçôes que reestruturaram o setor na década de 1990, até chegar no recente rompimento democrático, que aprofunda as medidas neoliberais nesse e nos demais setores.

A análise deste modelo energético é o mote do segundo capítulo do trabalho. A dinâmica de expansâo das fronteiras elétricas sobre a Amazônia e seus rios também pode ser depreendida da segunda seçấo do trabalho, compreendida a partir da relaçăo direta que detém com o desenvolvimento capitalista mundial. É dizer: a construçâo de duas usinas hidrelétricas no Rio Madeira năo está dissociada da questăo energética a nível nacional e dos processos globais do capital. A escolha pela construçâo das barragens, alimentando a matriz hidrelétrica, o local de sua implantaçâo, estrategicamente eleito, a forma como se dá o processo de licenciamento, o valor pré-ajustado da tarifa, até os processos de transmissâo e distribuiçâo da energia elétrica: todos esses fatores sâo influenciados e definidos a partir do modelo energético em curso no país.

Ao se falar do modelo utilizado năo se está referindo apenas à matriz energética, delineada a partir das fontes. Modelo aqui significa a política energética empreendida pelo Estado, que inclui a finalidade da produçăo de energia (energia para que e para quem?) tanto quanto a forma como é produzida (as fontes da produçāo de energia e o processo de sua exploraçăo, feito com respeito às gentes e à natureza, ou nâo).

O derradeiro capítulo realiza a análise minuciosa do processo de licenciamento ambiental das barragens do rio Madeira, abarcando e esmiuçando cada etapa do processo. Acredita-se que a identificaçāo das falhas nos processos de licenciamento ambiental de empreendimentos na Amazônia e das violaçôes de direitos causadas por essas obras seja essencial para a busca de outro modelo energético, menos violento e mais sensível à 
diversidade de formas de viver, lutar e amar. Somente a partir da realidade dos povos e outras coletividades considera-se possível a construçáo teórica e prática de seus direitos.

\section{BREVE HISTÓRICO DO SETOR ELÉTRICO BRASILEIRO}

O início da história do setor elétrico brasileiro (SEB) é marcado pela participaçăo de dois grupos estrangeiros, assim como o foi em toda a América Latina: Light e Amforp. Essa realidade foi se modificando lentamente, até o processo de estatizaçăo se estabelecer de fato, no começo da década de 1950 (MARTINS, 2009 e PINHEIRO, 2006).

O período entre 1929 e meados de 1933 foi marcado pela Depressăo Econômica Mundial, que abalou fortemente o sistema capitalista a nível global. A crise de 1929 provocou efeitos diretos na cafeicultura brasileira, que regulava o sistema político-econômico do país. Somente com a derrocada do café é que as classes sociais - e a própria burguesia associada à cafeicultura - começaram a perceber as limitaçóes de uma economia voltada ao mercado externo (IANNI, 1996). A Revoluçấo de 1930 foi resultado da crise política e econômica, ao mesmo tempo em que promoveu a aceleraçâo destas (MARTINS, 2009).

A Revoluçáo foi um marco no processo de industrializaçăo brasileiro. Na época, o sistema brasileiro de geraçăo e distribuiçăo de eletricidade năo era ainda integrado, atendendo a poucos centros urbanos e, em geral, aos interesses da economia agrário-exportadora. Era o suficiente até 1930, mas năo poderia acompanhar a crescente demanda após esse ano (MAGGI, 2013).

Com a crise política e econômica, mundial e interna, houve uma ruptura do Estado oligárquico vigente até entâo. Com a tomada de poder por Getúlio Vargas, o Estado Brasileiro foi reestruturado, passando a atuar com forte intervencionismo. No primeiro governo Vargas, houve uma nova forma de acumulação de capital, com o desenvolvimento da produçấo interna e a elevaçâo da produtividade, sempre acompanhadas por um sentimento de nacionalismo. Nas palavras de Ianni (1996, p. 22), “Passa-se do regime oligárquico à ditadura de tipo burguês, depois de um entreato de grande fermentaçâo política e cultural".

Para iniciar o processo de expansăo industrial, o país precisou de um novo arranjo institucional. Esse reordenamento teve início em setembro de 1931, quando foram suspensos todos os atos de alienaçăo, oneraçăo, promessa ou início de transferência de qualquer curso d'água. $O$ objetivo da medida era conter a concentraçăo do setor elétrico, compartilhada até entăo pelos grupos Light e Amforp (PINHEIRO, 2006).

Mas as principais mudanças no papel do Estado, particularmente no setor energético, se deram após o fim da cláusula ouro para os serviços de energia elétrica, por meio do Decreto n. 23.501, de 27 de novembro de 1933, e com a instituiçâo do Código de Águas, através do Decreto n. 24.643, de 10 de julho de 1934. A cláusula ouro era o mecanismo utilizado para a fixaçấo das tarifas desde a assinatura do primeiro contrato com a Sâo Paulo Light, e a sua extinçăo significava que as tarifas de energia elétrica passariam a ser fixadas conforme os custos de operaçáo e investimento. Além disso, com o Código de Águas, todos os recursos hídricos ficaram sob o monopólio estatal (PINHEIRO, 2006). 
O monopólio da água, gerida a partir do regime de concessâo, tornou-se disposiçấo constitucional a partir de 1937. Com o objetivo de regulamentar o Código de Ảguas e interligar o sistema elétrico nacional, foi criado, em 1939, o Conselho Nacional de Águas e Energia Elétrica (CNAEE) (MARTINS, 2009).

Até a década de 1940, essa forma de organizaçăo do setor permitiu que houvesse uma relaçăo confortável entre a oferta e a demanda de energia elétrica na sociedade brasileira. Mas novamente a sua expansăo năo acompanhou o ritmo das mudanças estruturais no modelo de desenvolvimento econômico que se deram nos anos seguintes, especialmente a industrializaçâo, mais intensa na década de 1950 (MARTINS, 2009).

Com a Segunda Guerra Mundial (1939-1945), a importaçâo de equipamentos para a construçấo de novas unidades geradoras foi interrompida. Isso nâo impediu que a produçâo de energia elétrica continuasse crescendo, mas em uma velocidade bem inferior ao crescimento da demanda. Além disso, năo havia interesse por parte do oligopólio estrangeiro em novos investimentos que possibilitassem alcançar a expansăo da demanda pela eletricidade (MARTINS, 2009).

Em 1945, com o fim da Segunda Guerra Mundial e, no Brasil, o fim do Estado Novo, passou-se de um sistema elétrico baseado no capital estrangeiro para os primeiros passos rumo à estatizaçăo. Sob o domínio estatal, houve a expansăo territorial do sistema elétrico. Assim, a eletricidade deixou de atender apenas aos grandes centros. Essa expansâo contribuiu, pouco a pouco, para a especializaçáo das empresas, seja na geraçáo, distribuiçāo ou transmissāo de energia elétrica (MARTINS, 2009).

Nesse período, foi criada a primeira empresa de eletricidade do governo federal, a Chesf. Além disso, criou-se o Fundo Federal de Eletrificaçăo (FFE) e o Imposto Único sobre Energia Elétrica (IUEE), năo sem um forte embate com os grupos estrangeiros que dominavam o setor, a Light e a Amforp. Enquanto o IUEE assegurava a receita voltada exclusivamente para o setor elétrico, o que permitiu a sua nacionalizaçāo, o FFE incentivou a criaçăo de empresas públicas estaduais do setor elétrico, já que determinava que os recursos destinados aos estados e municípios deveriam ser percebidos por uma empresa pública com esse fim (MARTINS, 2009).

Em 1951, foi instalada a Comissāo Mista Brasil-Estados Unidos de Desenvolvimento Econômico, tendo como objetivos a instalaçăo de novas indústrias e o desenvolvimento principalmente das áreas de energia e transportes. O financiamento desses projetos contou com fontes externas, como recursos provenientes do Banco Internacional de Reconstruçăo e Desenvolvimento (BIRD) e do Eximbank, e também com o financiamento e suporte do Programa de Reaparelhamento Econômico, instituído pela Lei n. 1.474, de novembro de 1951, e do Banco Nacional de Desenvolvimento Econômico, criado para a execuçấo dos planos do Programa, através da Lei n. 1.628, de junho de 1952 (DRAIBE, 1985).

Em 1954, foi enviado ao Congresso o primeiro Plano Nacional de Eletrificaçăo (PNE), com a finalidade de: elevar o potencial gerador de dois para quatro milhóes de quilowatts, unificar as correntes, padronizar as tensôes de transmissăo e equipamentos, dar início à indústria pesada de material elétrico no país, além de criar dois grupos de sistemas, um no Centro-Sul e outro, ao Norte, envolvendo as usinas isoladas (DRAIBE, 1985).

O Plano partia de bases regionais, dividindo o país em regiōes autossuficientes, para entâo interligá-las. O planejamento teria que ser centralizado em um único órgâo 
federal. A ampliaçăo do setor era, portanto, papel do Estado. A iniciativa privada, ou náo podia (no caso do capital nacional), ou náo queria (no caso do capital estrangeiro) investir os recursos necessários. Quanto à distribuiçăo da energia elétrica, por demandar menos investimento e permitir melhor retorno, era mais adequada ao capital privado (MARTINS, 2009).

Outro passo importante para a estatizaçâo do setor foi a criaçăo do Ministério de Minas e Energia (MME), em 1960, que reuniu sob uma única direçâo o Conselho Nacional de Águas e Energia Elétrica, o Departamento Nacional de Produçâo Mineral e a Chesf. O passo definitivo foi dado com a criaçâo das Centrais Elétricas Brasileiras S.A.(Eletrobrás), em 1961, e sua instalaçâo, em 1962. Os debates acerca da Eletrobrás se iniciaram ainda na década de 1950, quando foi criada também a Petrobrás, mas o projeto de lei tramitou durante quase oito anos no Congresso Nacional, com forte oposicionismo dos setores privatistas (MARTINS, 2009).

A criaçăo da Eletrobrás se deu em um período de crise política. Com a renúncia de Jânio Quadros, em 1961, Joâo Goulart assumiu o governo, pressionado, de um lado, pela esquerda que o apoiava e aguardava reformas estruturais e, de outro, pelos setores mais conservadores, que temiam a crescente participaçăo sindical no governo. Essa instabilidade conduziu ao golpe civil-militar de 1964, que afastou o governo de Joăo Goulart de forma autoritária (SOUZA, 2013).

As justificativas para a execuçâo do golpe, além do combate ao comunismo, basearam-se na suposta necessidade de restabelecimento da ordem social e retomada da expansăo econômica. Dessa forma, o novo período teve como objetivo a consolidaçăo do modelo implantado nos anos 1950, de expansáo e concentraçấo econômica. Durante os sucessivos governos militares, o Estado se configurou como centralizador e autoritário.

Nesse contexto, foi criado o Departamento Nacional de Águas e Energia Elétrica (DNAEE), órgâo normativo e fiscalizador, que assumiu as funçōes do extinto CNAEE, responsável pela outorga das concessōes. A política energética era formulada pelo MME e executada pela Eletrobrás, que era composta por seis empresas subsidiárias: quatro empresas federais eram responsáveis pela geraçăo e transmissăo de energia elétrica (Furnas, Eletrosul, Chesf e Eletronorte) e duas pela distribuiçăo (Light e Escelsa). O setor era composto ainda por 60 empresas concessionárias, das quais mais da metade eram federais e estaduais, e o restante privadas (PINHEIRO, 2006).

Em 27 anos (1962-1989), a capacidade instalada do setor elétrico brasileiro cresceu 736\%. Entre os anos de 1969 e 1981 ocorreu o auge da expansăo elétrica, com crescimento médio anual de 11,3\%. A partir daí, com a crise econômica que recaiu sobre a economia brasileira, o crescimento sofreu uma queda brusca, de 12,03\% em 1981 para 3,89\% em 1985 (MARTINS, 2009).

Se, por um lado, a forte atuaçăo estatal permitiu essa expansâo da capacidade instalada, de outro o autoritarismo contribuiu para uma forma particular de organizaçáo do setor, baseada na construçăo de grandes barragens, que acompanhava os demais projetos faraônicos implantados pela ditadura militar, símbolos do Brasil potência. A opçâo pela construçăo de grandes barragens teve início a partir da década de 1970 e, apesar da redemocratizaçăo, nâo se encerrou até os dias de hoje. 
O que mudou no período seguinte foi o papel do Estado. Todo o investimento realizado no setor elétrico, a expansáo das fronteiras e da capacidade instalada e a tecnologia desenvolvida pelo país até aquele momento foram repassados à iniciativa privada. Os anos 1990 foram marcados pela desestruturaçăo do setor e pela venda das estatais.

Após a redemocratizaçăo, teve ascensăo uma onda neoliberal, com críticas à atuaçăo estatal (o gigante ineficiente) abrindo espaço para as empresas privadas, amparada por novo ordenamento jurídico do setor. Em 1990, foi criado o Programa Nacional de Desestatizaçăo (PND), no governo Fernando Collor de Mello. A reestruturaçăo do sistema elétrico brasileiro estava prevista no programa, com a sua desverticalizaçăo, fragmentando o setor entre os segmentos monopolistas, transmissăo e distribuiçâo, e os nâo monopolistas, geraçăo e comercializaçấo (PINHEIRO, 2006).

O marco legal do início do novo período foi a promulgaçăo da Lei n. 8.631, de 04 de março de 1993, que deu ao setor um caráter mais empresarial. Antes, a tarifa de energia era uma só em todo o território nacional, a partir do custo do serviço, e as concessionárias possuíam o direito à remuneraçăo garantida. Assim, quando as concessionárias obtinham remuneraçăo superior à garantida, o excedente era recolhido a um fundo, que garantia a remuneraçâo daquelas com rentabilidade inferior. A Lei extinguiu o regime de remuneraçâo garantida e os níveis das tarifas para o serviço público de energia elétrica passaram a ser definidos pelas concessionárias - as empresas propóem e o poder concedente homologa (PINHEIRO, 2006).

Além disso, o Decreto 915, de 06 de setembro de 1993, Decreto 1009, de 22 de dezembro de 1993 e a Portaria 337, de 22 de abril de 1994, todos publicados durante o governo Itamar Franco, autorizaram a formaçâo de consórcios para a geraçăo de energia elétrica, inclusive entre concessionárias e autoprodutores, e criaram o Sistema Nacional de Transmissāo de Energia Elétrica (SINTREL), permitindo o livre acesso da iniciativa privada à rede de transmissâo de energia, podendo os produtores independentes revender a eletricidade em qualquer ponto interligado do país (PINHEIRO, 2006). Essas reformulaçôes eram incentivadas, financiadas e foram inclusive saudadas pelo Banco Mundial (VAINER, 2007).

Essas normas sedimentaram o caminho para o que viria a seguir. É no governo Fernando Henrique Cardoso (FHC) que o monopólio estatal sobre o petróleo e gás natural e sobre as telecomunicaçōes é quebrado. Inicialmente, com a promulgaçâo da Lei n. 8.987, de 13 de fevereiro de 1995, a Lei Geral das Concessóes de Serviços Públicos, "'construída' distante do Congresso e no interior das sedes das grandes empreiteiras brasileiras" (MARTINS, 2009, p. 86). É essa Lei que permite, por exemplo, as desapropriaçôes de terras promovidas pelas concessionárias. Data do mesmo ano a Lei n. 9.074, de 07 de julho de 1995, que estabeleceu a definição de aproveitamento ótimo hidrelétrico - quanto mais geraçăo da mercadoria energia, melhor. Ambas as normas foram alteradas em 1998, pela Lei 9.648, de 27 de maio, que estabelece como vencedora da licitaçăo a candidata que apresente menor valor da tarifa ou maior oferta pela outorga da concessáo (outorga onerosa) (PINHEIRO, 2006).

No governo FHC houve uma remodelaçăo do PND a partir das diretrizes estabelecidas pelo Projeto de Reestruturaçáo do Setor Elétrico Brasileiro (RE-SEB). O Projeto foi elaborado pelo consórcio liderado pela empresa britânica Coopers \& Lybrand, do qual 
participaram as brasileiras Ulhôa Canto Advogados, Engevix e Main Engenharia, a norte-americana Latham \& Watkins e a inglesa Rust Kennedy \& Donkin (MARTINS, 2009).

A reestruturaçăo fundava-se nas necessidades do mercado, portanto, as orientaçóes visavam, em resumo, estimular o investimento e reduzir o risco aos investidores, ampliar a oferta de energia e a competiçấo, balizadas pela eficiência (produtividade, melhor rendimento $x$ menor custo), garantindo a qualidade de acordo com a necessidade do mercado. Para isso, foi preciso redefinir as funçōes da Eletrobrás e fortalecer o órgáo regulador, permitindo a instituiçâo de um mercado de livre concorrência de energia e a fragmentaçăo do setor em geraçâo, transmissâo, distribuiçâo e comercializaçâo. Reestruturar as subsidiárias federais para apenas um segmento facilitou a sua privatizaçăo (MARTINS, 2009).

A proposta da Federaçăo das Indústrias do Estado de Sáo Paulo (FIESP) para o país é expressa no texto Livre para crescer (1990), que inicia afirmando que "o Brasil está doente" e que "caminha assolado por violência, corrupçáo e decadência de valores". A "proposta para um Brasil moderno" é a abertura da economia ao exterior e a desregulamentaçăo das relaçôes econômicas. Sobre a Eletrobrás, a FIESP (1990) afirma o seguinte:

O ônus causado pelo elevado endividamento das estatais e a consequente desordem contábil refletem-se claramente no balanço das Centrais Elétricas Brasileiras - Eletrobrás -, a holding responsável pela coordenaçăo técnica, financeira e administrativa do fornecimento de energia elétrica no país (FIESP, 1990, p. 272).

Com discurso semelhante e no mesmo período, foram privatizadas a Companhia Vale do Rio Doce e a Telebrás. No setor elétrico, foi vendida uma das principais subsidiárias da Eletrobrás, a Eletrosul. As distribuidoras federais, Escelsa e Light (estatizada no período anterior), incluídas no PND desde o governo Collor, foram leiloadas durante o governo FHC, em 1995 e 1996. As concessionárias estaduais seguiram o mesmo caminho (MARTINS, 2009).

A criaçâo da Agência Nacional de Energia Elétrica (ANEEL) foi fundamental para sustentar esse modelo. A ANEEL assumiu as funçóes do DNAEE, conduzindo os processos de licitaçăo e outorga de concessôes para aproveitamento hidrelétrico e de implementaçâo de termelétricas. O Mercado Atacadista de Energia (MAE), criado dois anos mais tarde, proporcionou o livre mercado de energia. E o Operador Nacional do Sistema Elétrico (ONS) assumiu a gestăo e controle das instalaçōes de geraçăo e transmissăo de energia elétrica no sistema interligado (MARTINS, 2009).

Entre 1995 e 2000, a participaçăo do capital privado na capacidade instalada aumentou de $2,7 \%$ para $22 \%$, e as concessionárias privadas expandiram sua participaçăo na distribuiçấo, que antes era de $2,4 \%$, passando para $63 \%$. Com isso, ingressaram novos agentes no SEB: o consórcio brasileiro VBC Energia, formado pelos grupos Votorantim, Bradesco e Camargo Corrêa; a brasileira Cataguazes-Leopoldina (hoje Grupo Energisa); a estatal francesa EDS; as norte-americanas AES, Duke Energy e Enron; as espanholas Endesa e Iberdrola; a portuguesa EDP; e a belga Tractebel (MARTINS, 2009).

Após as privatizaçōes, a Eletrobrás ficou sendo constituída por sete subsidiárias, fragmentadas entre os segmentos: Chesf, Furnas e Eletronorte na geraçâo e transmissâo, 
Eletronuclear (fornecedora de energia nuclear), CGTEE na geraçăo, Eletrosul na transmissăo e Ligthpar em participaçôes (hoje Eletropar) (MARTINS, 2009).

Apesar das orientaçôes do SEB para o mercado, o governo FHC foi marcado por "instabilidade nas taxas de rentabilidade das maiores empresas", conduzindo "as empresas a momentos de oscilaçôes e, notadamente nos anos de 1999 e 2002, de prejuízos financeiros" (MARTINS, 2009, p. 92).

Sinteticamente, a expansăo da geraçăo elétrica brasileira no período 1990-2000 parece ter ficado na expectativa da definiçáo do novo modelo de mercado. Por um lado, as empresas que se mantiveram estatais investiram menos na expansăo da geraçấo, năo foram estimuladas pelos governos a isso e, além disso, tiveram acesso a um volume menor de crédito por parte das instituiçóes financeiras, notadamente, o BNDES (...). Do outro lado, as empresas privadas pareceram ter algum receio de investir em um cenário de incertezas e náo conseguiram manter um ritmo acelerado de expansâo. Assim, a passagem para o modelo concorrencial de mercado foi mais complicada do que a expectativa dos seus idealizadores, o que gerou uma série de questionamentos acerca da implementaçâo do programa de desestatizaçâo. Já a partir de 2000, a superaçáo da fase transiçăo, as parcerias entre as empresas estatais e privadas e a retomada da linha de financiamento pelo BNDES permitiram uma etapa de maior expansăo (MARTINS, 2009, p. 101).

Assim, o papel do BNDES, como "entidade central nas privatizaçôes" (VAINER et. al., 2015, p. 74), foi fundamental para a consolidaçăo do atual modelo energético. Ele é o principal financiador da construção das usinas hidrelétricas, repassando dinheiro público para a iniciativa privada, inclusive para as empresas transnacionais. Com isso, os investidores ganharam segurança, possibilitando inclusive o aumento dos lances nos leilōes (VAINER et. al., 2015).

Após 2003, os ajustes promovidos pelo governo Lula năo romperam com a lógica de mercado. Ao contrário, os projetos de geraçâo baseados em parcerias público-privadas permitiram às empresas privadas investir valores menores e, ao mesmo tempo, manter o controle sobre o empreendimento. Com o governo Lula, houve um aumento expressivo nos lucros das companhias, especialmente a Cemig, a Tractebel e a CPFL (MARTINS, 2009).

O governo dialoga com interesses aparentemente conflitantes: o grande capital, políticas sociais e ampliaçâo de crédito para as parcelas da populaçăo de menor renda (VAINER et. al., 2015). Aparentemente porque, embora essas medidas tenham provocado profundas e benéficas mudanças para as classes populares, o modelo energético seguiu se consolidando e ampliando cada vez mais as fronteiras elétricas, a mâo-de-obra para o setor e os mercados consumidores.

Por outro lado, a privatizaçáo foi interrompida com o retorno do investimento nas estatais e as agências reguladoras, a Agência Nacional de Petróleo (ANP) e a Agência Nacional de Energia Elétrica (ANEEL), desempenharam, por vezes, um papel diferente daquele para o qual foram criadas. O Operador Nacional do Sistema (ONS) e a Empresa de Pesquisa Energética (EPE) também tiveram um papel regulamentador mais ativo (ROSA, 2015).

O governo Dilma, Ministra de Estado de Minas e Energia no período anterior, manteve a forma de atuaçăo predecessora, dando continuidade aos projetos já em execuçăo, como as hidrelétricas de Santo Antônio e Jirau, no rio Madeira, e iniciando outros nâo tăo 
novos assim, como a construçâo da usina hidrelétrica de Belo Monte, idealizada ainda na ditadura militar e projetada também no governo FHC.

Para tanto, o governo editou a Medida Provisória 558/2012, em 06 de janeiro daquele ano, convertida na Lei n. 12.678, de 25 de junho de 2012, alterando os limites de diversas Unidades de Conservaçăo da Amazônia: Parque Nacional da Amazônia, Parque Nacional dos Campos Amazônicos, Parque Nacional Mapinguari, Floresta Nacional de Itaituba I e II, Floresta Nacional do Crepori e Área de Proteçáo Ambiental do Tapajós. Essa alteraçâo retirou das áreas protegidas o espaço necessário para comportar os reservatórios das usinas do Madeira e do Xingu, abrindo caminho também para as hidrelétricas previstas para a Bacia do rio Tapajós (BERMANN, 2012 e BRASIL, 2012).

A extensáo dos planos brasileiros de construçâo de hidrelétricas na Amazônia somente foi revelada uma vez, no Plano 10, liberado em 1987, que listava o total de 79 barragens planejadas. Desde entâo, vêm sendo liberados planos para curtos intervalos, que năo preveem o aproveitamento total planejado (FEARNSIDE, 2016). De acordo com o último plano elaborado durante o governo Dilma, o Plano Decenal 2024 (MME, 2015), a expansăo hidrelétrica prevista entre os anos de 2015 e 2024 é de 28.349 megawatts, além dos outros 15 projetos de usinas hidrelétricas com estudos de viabilidade aprovados ou com aceite na ANEEL, que somariam aproximadamente 4.200 megawatts. $O$ acréscimo de capacidade instalada estava previsto quase que em sua totalidade para a Regiăo Norte (MME, 2015). No Plano Decenal 2027 (MME, 2017), elaborado após o rompimento democrático, durante o governo Michel Temer, os números de geraçáo hidrelétrica diminuem, no entanto o foco permanece no potencial remanescente no Norte e Centro-Oeste, com destaque para a expansăo da transmissăo, com a implantaçăo de $55.240 \mathrm{~km}$, um aumento de 38\% na extensấo do sistema.

De toda a energia consumida no ano de 2015, apenas 9,6\% foi direcionada ao consumo residencial, segundo dados oficiais do Balanço Energético Nacional (MME, 2016). Prioriza-se a distribuiçáo para a produçâo industrial, em especial a eletrointensiva, composta por seis setores: cimento, produçâo de aço, alumínio (metais năo ferrosos), ferro-ligas (ramo da metalurgia), petroquímica e indústria de papel/celulose. Essa distribuiçâo é economicamente desfavorável, já que săo produtos que demandam alto conteúdo energético, ao passo que possuem baixo valor agregado (BERMANN, 2015).

Quanto às medidas de caráter popular, o governo Dilma renovou as concessôes de hidrelétricas antigas, contrariando os interesses da Federaçāo das Indústrias do Estado de Săo Paulo. Com o objetivo de reduçăo das tarifas de energia elétrica, que haviam tido um aumento com as privatizaçóes, principalmente das distribuidoras, reduziu a remuneraçăo da geraçâo elétrica pelas usinas consideradas amortizadas. O problema é que a medida impactou particularmente as geradoras federais, empresas do grupo Eletrobrás (ROSA, 2015).

É a partir dessas tentativas de conciliaçâo de interesses obviamente inconciliáveis que se forja o modelo energético em curso no país. Este modelo que vem se tornando mais perverso desde a ruptura democrática ocorrida em 2016, que acelerou ainda mais o processo de mercantilizaçáo dos recursos naturais e vem ameaçando um regresso ao período das privatizaçōes. 
O governo Bolsonaro segue com a proposta de privatizaçăo da Eletrobrás, o que pode acarretar em menor controle estatal sobre os recursos hídricos de que dispóe, além de um aumento na tarifa de energia elétrica, regredindo nas políticas públicas instauradas em anos anteriores de acesso à luz. $O$ corte de investimentos nas estatais já vem gerando, nos últimos anos, uma demissăo em massa dos trabalhadores da Eletrobrás, especialmente da subsidiária Furnas.

\section{O ATUAL MODELO ENERGÉTICO}

O modelo energético consolidado, sob o qual foram construídas as hidrelétricas do Rio Madeira, é, portanto, baseado na lógica de mercado. A distribuiçăo foi majoritariamente privatizada e houve uma ampliaçăo da participaçăo privada também na geraçâo. Os segmentos do setor elétrico brasileiro agora sâo compostos ainda pelas atividades de importaçăo e exportaçăo (CCEE, 2017).

Os consórcios formados para a geraçâo de energia elétrica sâo constituídos predominantemente por açôes de capital privado, e geralmente com alguma participaçăo de estatais, o que reduz o investimento das transnacionais. Além disso, o BNDES figura como principal financiador da construçâo das usinas, reduzindo os riscos. As concessóes garantem, desde o início, a compra da energia pelo Estado por, pelo menos, trinta e cinco anos (BRASIL, 1995).

Mesmo assim, de acordo com a ANEEL (2016), o consumidor cativo paga pela compra da energia (custos do gerador), pela transmissáo (custos da transmissora) e pela distribuiçâo (serviços prestados pela distribuidora), além de encargos setoriais e tributos. Consumidor cativo é o consumidor residencial ou de pequenos comércios, que é obrigado a comprar a eletricidade da concessionária ou permissionária detentora do monopólio na regiăo. Além do consumidor cativo, existe o consumidor livre, que é atendido em qualquer tensấo e pode optar pela compra de energia elétrica de qualquer fornecedor. Sâo livres as grandes empresas e as indústrias.

Hoje, a energia elétrica é tratada como mercadoria. Ela possui um preço de produçâo médio geral, influenciado pelo custo de produçâo médio das fontes dominantes, ou seja, da geraçâo térmica a partir de combustíveis fósseis. Esse preço geral expressa o preço do custo de produçáo médio da eletricidade nas piores condiçôes de produtividade. Assim, o preço médio de produçăo por unidade de eletricidade é calculado com base no custo de produçấo a partir de fontes térmicas somado à taxa de lucro média do capital (GONÇALVES JUNIOR, 2007).

O preço da geraçâo hidráulica, principal fonte energética brasileira, é relativamente baixo, bem inferior ao preço da geraçáo térmica. A energia gerada a partir das usinas hidrelétricas depende de um elemento da natureza: o movimento das águas dos rios. Gerar energia a partir das águas dos rios tem um custo menor que promover a combustáo de combustíveis fósseis, que demanda o emprego de maior força de trabalho. Aí está a lucratividade da geraçâo de energia hidrelétrica no atual modelo energético: o preço da energia elétrica brasileira está vinculado ao custo da energia térmica. Dorival Gonçalves (2007, p. 165) explica da seguinte forma: 
Assim, recuperando que o preço de produçăo da eletricidade é dado pelo custo de produçấo na pior condiçáo de geraçấo adicionado a taxa de lucro médio geral do capital aplicada à totalidade das instalaçôes, ou seja, é o preço de produçâo médio para geraçấo de eletricidade a partir dos combustíveis fósseis que constitui o preço regulador do mercado. Náo se trata aqui do preço exato da mercadoria eletricidade. Mas, é ele o preço em torno do qual o preço da eletricidade oscila no mercado e é geralmente vendida. Daí os empreendedores em geraçáo de eletricidade que dispóem de potenciais hidráulicos podem obter lucros suplementares (...).

Este lucro suplementar ou extraordinário ocorre quando se investe em bases naturais com uma grande produtividade, ou seja, que geram mais riquezas com menos trabalho. É por isso que grandes empresas, especialmente as transnacionais, disputam territórios como a Amazônia, estratégicos do ponto de vista da lucratividade.

Alberto Acosta (2016) recorda a premissa segundo a qual os países ricos em recursos naturais sâo também os menos desenvolvidos, os países pobres, como numa "maldiçâo dos recursos naturais". Esse discurso, defendido inclusive pelo Banco Interamericano de Desenvolvimento (BID), corrobora com a prática de sustento das economias dos países ricos em funçăo da exploraçâo dos recursos naturais existentes naqueles destinados a tal maldiçăo.

A partir desta análise, é fácil entender o interesse nas jazidas que se encontram no solo, na mata e nos rios amazônicos. E por isso Acosta (2016, p. 59) conclui que "grandes beneficiárias dessas atividades săo as empresas transnacionais, que assim colhem os frutos pelo 'mérito' de terem se arriscado a procurar e explorar os recursos naturais algumas vezes em áreas inóspitas".

A tática das transnacionais, năo apenas no ramo da energia, mas com o extrativismo da natureza em geral, é, portanto, "transformar espaços onde se encontram os recursos naturais considerados estratégicos em territórios eficientes e produtivos" (SVAMPA, 2016, p. 159). É essa dominaçâo dos territórios que permite, por exemplo, que a energia elétrica seja gerada com o objetivo de subsidiar a atividade mineradora.

Esta forma de atuaçăo das empresas e governos năo é novidade. Na verdade, ela vem sendo a garantia de perpetuaçâo do modelo econômico. Há que sempre ter algum ouro, ferro, soja ou energia mais a frente. E há que sempre ter um mercado que dê conta da nova produçăo.

Na busca constante por recursos naturais rentáveis, o que se apresenta como característica contemporânea do atual modelo energético é justamente o deslocamento da fronteira elétrica (CASTRO, 1985) para a Amazônia, esta que já representou tantas fronteiras.

A Amazônia concentra a maior parte do potencial de geraçâo de energia hidrelétrica no país (ANEEL, 2005). Além disso, o acesso a este território năo se limita à exploraçáo da energia proveniente de seus rios, mas representa o ingresso em porçôes territoriais estratégicas, se náo pelos recursos minerais e energéticos, pelo acesso às terras - de povos e comunidades tradicionais - que podem produzir mais mercadorias e às possíveis rotas de acesso hidroviário e rodoviário que atravessam o continente para escoar tudo o que for produzido ou extraído da natureza.

Os planos de aproveitamento hidrelétrico năo se limitam à Amazônia brasileira, mas estăo focados principalmente no Brasil, Peru e Bolívia. Também existem projetos para o Equador, Colômbia, Venezuela, Guiana e Suriname. A importância geopolítica do Brasil 
se dá năo apenas pelo enorme potencial hidrelétrico, mas porque é também financiador e construtor de barragens nos países vizinhos (FEARNSIDE, 2016).

O começo da eletrificaçăo na Amazônia se deu de forma localizada: eram pequenas geraçôes, sempre direcionadas a determinados empreendimentos privados, ou pequenas iniciativas residenciais. Na regiăo do Rio Madeira, em 1908, já havia instalaçôes elétricas que suportavam as necessidades da Estrada de Ferro Madeira-Mamoré (LEMOS, 2007).

Com o passar dos anos, a energia elétrica que era gerada na Amazônia, a partir das termelétricas, anunciava o desenvolvimento da regiâo. Um modelo claro e específico de desenvolvimento que seria imposto às populaçôes nativas, com ares de progresso e modernizaçấo. Era esse o declarado objetivo da Superintendência do Plano de Valorizaçăo Econômica da Amazônia (SPVEA) e da sua sucessora, a Superintendência de Desenvolvimento da Amazônia (SUDAM), pelo menos até o ano de 1974 (LEMOS, 2007).

Entre os anos de 1975 e 1985, a expansâo das fronteiras era vista como fundamental à integraçăo energética do país, ou seja, vislumbra-se a possibilidade de a força das águas amazônicas servirem ao desenvolvimento da industrializaçâo nas demais regiôes brasileiras (LEMOS, 2007) e também à internacionalizaçăo da economia brasileira.

Para isso, a propaganda sobre a regiâo divulgava o "enorme potencial hidrelétrico, tendo como em contrapartida a baixa demanda regional; ênfase no esgotamento das fontes hídricas para produçâo de energia elétrica em outras regiōes" (LEMOS, 2007, p. 308) e associava as riquezas naturais à disponibilidade de tecnologia, que fatalmente conduziriam o país ao progresso.

Enquanto se construía as possibilidades de ligaçăo do sistema elétrico nacional, foi preciso encontrar outro fundamento para a geraçăo de energia hidrelétrica na regiâo Norte do país. Foi necessário criar um mercado mais próximo para direcionar toda a energia que seria gerada.

(...) Quando se pensa em termos de desenvolvimento da regiăo amazônica. Năo temos grandes consumidores de energia elétrica, porque náo há energia elétrica. Nâo há energia elétrica, năo construímos usinas de grande capacidade, porque năo há consumo de energia elétrica. (...) Vamos construir Tucuruí, custe o que custar, mas em fins de 1981/1982 teremos energia elétrica de forma abundante na regiăo. (...) Devemos criar, no Setor Elétrico, mentalidade de marketing agressiva. Temos de buscar o consumidor, industrial e induzi-lo a consumir a nossa energia elétrica. Precisamos alterar um pouco a nossa atitude de esperar que o consumidor venha até nós. (...) Nós é que devemos procurar um milionário ou outro e dizer-lhe: é bom negócio consumir energia elétrica e fabricar alumínio. Nós daremos transformador, puxaremos linha de transmissăo até lá, vamos procurar uma tarifa que lhe dê condiçôes de ser um grande fabricante de alumínio. Nós podemos, inclusive em termos de tarifa, ser bastante flexíveis, coisa que nunca sucedeu (...) Vamos citar o alumínio como exemplo: determinado industrial diz năo ser possível montar uma fábrica de alumínio a 15 mils, na cidade de Belém, porque o alumínio está custanto 800 dólares a tonelada, no mercado mundial (...) Nós pretendemos criar uma política no sentido de que (...) [possamos] responder ao industrial que venderemos a um preço em que o negócio passe a ser viável. (...) É um mecanismo que em nossa opiniǎo o Brasil deve adotar com a maior urgência possível, para que novas fábricas de níquel, zinco, alumínio, ferro-liga, eletro-siderurgia etc., possam ser ampliadas com o setor de energia elétrica bancando o risco. Essa palavra é muito perigosa, mas 
de certa forma assumimos o risco de comportamento do mercado. Deveríamos estar, hoje, exportando centenas ou milhôes de dólares de alumínio. E estaríamos exportando energia: cada tonelada de alumínio estaria exportando entre 15 e 20 kwh aproximadamente (UEKI, 1975 apud LEMOS, 2007).

A primeira hidrelétrica a entrar em operaçăo na Amazônia brasileira foi a UHE do Paredâo, em 1976, no rio Araguari (Amapá). A UHE do Paredăo, da estatal Eletronorte, tinha como finalidade subsidiar com a eletricidade a exportaçáo do manganês, explorado pela Icomi, sociedade entre o brasileiro Antunes, de Minas Gerais, e a norte-americana Bethlehem Steel (SEVÁ; GARZON; NÓBREGA, 2011).

Nesse contexto, também săo construídas as usinas hidrelétricas de Tucuruí (Pará), Balbina (Amazonas) e Samuel (Rondônia). Tucuruí serviu ao abastecimento das indústrias eletrointensivas implantadas no estado do Maranhăo e no Pará: Albrás/Alunorte e Alcoa/Alumar, além do Projeto Grande Carajás. A construçáo de Balbina representou uma decisáo política, baseada em dados imprecisos e projetos equivocados, com a finalidade de năo criar conflitos com a elite local, que ansiava por grandes projetos na regiăo. Enquanto a usina hidrelétrica de Samuel, no Rio Jamari, afluente do Rio Madeira, esteve associada às políticas de ocupaçăo e domínio do território (LEMOS, 2007). Entram aqui também os projetos para a construçăo do Complexo Hidrelétrico do Xingu.

O papel da Eletronorte foi fundamental neste processo. Ao assumir os parques geradores das capitais, subordina-os ao desenvolvimento nacional. Se antes o objetivo era perpetuar um modelo de desenvolvimento imposto à regiấo, com a constituiçăo da Eletronorte os recursos locais sâo apropriados para servir à expansăo das indústrias nacional e internacional (LEMOS, 2007).

Na década de 1990, com as privatizaçóes, o setor elétrico foi reformulado a partir da lógica competitiva de mercado. O papel da Amazônia, no entanto, năo foi alterado no novo cenário, apenas se intensificou a exploraçăo da regiăo enquanto jazida energética. De acordo com Lemos (2007, p. 310): "o novo contexto privatizante reitera os mega-empreendimentos [sic] hidrelétricos como modelo de exploraçấo desses recursos".

A análise das grandes obras de barragens planejadas e executadas na Amazônia no final do século XX e no início do século XXI proporciona a compreensáo da dimensăo real desta ofensiva na Amazônia. Na mesma velocidade que se planeja e licencia as obras, se reproduzem os erros, repetidos a cada rio barrado, as violaçôes de direitos e as consequências ainda incalculáveis. Neste cenário se incluem as barragens construídas no Rio Madeira, no estado de Rondônia.

\section{BARRAGENS NO RIO MADEIRA}

Oprocesso de construçâo das barragens de geraçâo de energia elétrica no Rio Madeira năo pode ser analisado apartado de um contexto maior, que é o modelo energético em curso no país. A mercantilizaçăo da energia, a privatizaçấo de partes do setor elétrico brasileiro e a incursâo de empresas transnacionais, com financiamento público, sâo essenciais para compreender a lógica sob a qual se alicerçam as barragens.

A ediçăo da citada Lei 9.074/1995 foi fundamental para isso. Até entăo, as empresas estatais dividiam o domínio territorial do país. Com a reestruturaçăo do setor elétrico e 
a autorizaçăo dos consórcios com as empresas privadas, Furnas Centrais Elétricas S.A. pôde expandir a sua atuaçăo para além da regiăo Sudeste (MONTEIRO, 2011).

Em 1999, Furnas formou parceria com a Construtora Norberto Odebrecht S.A. para a construçăo da usina hidrelétrica de Manso, no Mato Grosso. O lucro rápido alcançado com Manso levou Furnas e Odebrecht a elaborarem estudos de inventário de outros rios estratégicos. Assim, iniciaram os estudos sobre o aproveitamento hidrelétrico do Rio Madeira (MONTEIRO, 2011).

O projeto do Complexo Hidrelétrico Rio Madeira possui duas justificativas e, portanto, duas finalidades distintas, mas que se complementam no desenvolvimento do sistema capitalista. Por um lado, a justificativa geral para os projetos hidrelétricos na Amazônia: o esgotamento das fontes hidráulicas no sul e sudeste, somado à necessidade de abastecimento dessas regiôes e o enorme potencial dos rios amazônicos. De outro, a ambiçăo histórica de domínio das águas do rio e utilizaçấo da rota para a circulaçăo de mercadorias.

A escolha do local de implantaçâo das barragens foi motivada justamente pela viabilizaçâo da navegaçăo, sendo ignorados os impactos socioambientais consequentes desta decisâo. Para isto, as usinas hidrelétricas de Santo Antônio e Jirau foram apenas o início do Complexo Hidrelétrico (LEME ENGENHARIA LTDA., 2005a).

Oprojeto das quatro usinas hidrelétricas, com a malha hidroviária, está incluído numa regiăo estratégica da chamada Pan-Amazônia. Esta, por sua vez, constitui um dos principais eixos de investimento da Iniciativa para Integraçăo da Infra-Estrutura Regional Sul Americana (IIRSA). Além de projetos energéticos e hidrovias, a IIRSA compreende outros planos de infraestrutura para integraçăo, como rodovias, ferrovias e portos, para o escoamento da produçấo pelo Oceano Pacífico para os mercados asiáticos. Por isso, investe também na exploraçăo de minérios, agropecuária e da própria biodiversidade, mercantilizada (ALMEIDA, 2009). Hoje, a IIRSA existe no âmbito da Uniâo de Naçóes Sul-Americanas (UNASUL) e como parte do fórum técnico do Conselho Sul-Americano de Infraestrutura e Planejamento (COSIPLAN) (OLIVEIRA JUNIOR; VAZ, 2017).

O Complexo Madeira se insere ainda no âmbito do PAC, tendo sido noticiado por anos como a maior obra do Programa. De acordo com Almeida (2009, p. 20): "O PAC tem como propósito correlacionar infraestrutura energética com infraestrutura logística e com o que chamam de 'infraestrutura social'. Entretanto, a ideia de território e dos povos e comunidades correspondentes acha-se ausente (...)".

Para a IIRSA, a Amazônia, com seus rios năo navegáveis, densa floresta e territórios de populaçōes tradicionais, representa um obstáculo à integraçăo dos países da América do Sul. Integrar, para a IIRSA, năo é diferente da forma utilizada na década de 1970, nos projetos de colonizaçāo da Amazônia. O obstáculo é à exploraçăo e exportaçáo dos recursos naturais da floresta. É exatamente a mesma concepçăo do PAC que, em uma escala menor, enxerga toda a imensidăo da floresta como mercadoria pronta para ser reivindicada, já que năo há gentes morando ali. Há índios. E, os índios, um dia, terăo que ser também integrados (LEROY; MALERBA, 2010). Sob essa lógica săo planejadas as hidrelétricas no Rio Madeira.

Analisar a forma como foram conduzidos o estudo prévio de impacto ambiental (EPIA ou EIA) e o licenciamento ambiental é fundamental para compreender o objetivo 
final com a construçăo das obras, os interesses que estavam em jogo e, finalmente, para avaliar as violaçôes de direitos humanos e socioambientais que tiveram como causa as usinas hidrelétricas de Santo Antônio e Jirau, desde o seu planejamento.

O licenciamento ambiental é um dos instrumentos da Política Nacional do Meio Ambiente, e a sua realizaçăo está prevista na Lei n. 6.938, de 31 de agosto de 1981, sempre que houver a construçâo, instalaçăo, ampliaçâo e/ou funcionamento de estabelecimentos e atividades que utilizem recursos ambientais e que possam, de alguma maneira, poluir ou degradar a natureza (BRASIL, 1981). Dessa forma, o licenciamento se propóe a resguardar o ambiente de atividades potencialmente danosas, protegendo a fauna, a flora, o solo, os cursos de água e qualquer outro elemento da natureza, assim como as gentes, ou seja, protege a vida em todas as suas formas.

Além disso, o licenciamento ambiental é regulamentado ainda pelas Resoluçōes $n$. 001, de 23 de janeiro de 1986, 237, de 19 de dezembro de 1997 e 279, de 27 de junho de 2001, do Conselho Nacional do Meio Ambiente (CONAMA) e pela Lei Complementar 140, de 08 de dezembro de 2011, que alterou a Lei 6.938/1981. A Resoluçáo 279/2001 do CONAMA trouxe um retrocesso nas garantias estabelecidas anteriormente, ao criar o licenciamento ambiental simplificado, para empreendimentos elétricos com pequeno potencial de impacto ambiental. Os empreendimentos podem ser usinas hidrelétricas, termelétricas, linhas de transmissâo e subestaçōes, além de usinas eólicas e outras fontes alternativas. A Resoluçáo náo discrimina o que seria o pequeno potencial de impacto ambiental, e relega esta decisăo ao órgâo ambiental quando da análise do requerimento de Licença Prévia protocolado pelo empreendedor em conjunto com o Relatório Ambiental Simplificado (CONAMA, 2001).

A competência pelo licenciamento ambiental de grandes empreendimentos hidrelétricos é, a rigor, do Instituto Brasileiro do Meio Ambiente e dos Recursos Naturais Renováveis (IBAMA). Salvo se os impactos do empreendimento estiverem limitados a uma localidade municipal ou regiâo estatal, cabendo, respectivamente, ao órgáo ambiental municipal ou estadual, ou quando o órgâo federal delegar expressamente a competência aos estados (CONAMA, 1997).

No caso da construçâo de hidrelétricas, com capacidade de geraçăo acima de 10 megawatts, o licenciamento depende da elaboraçăo de Estudo de Impacto Ambiental (EIA) e respectivo Relatório de Impacto sobre o Meio Ambiente (RIMA) (CONAMA, 1997). A Constituiçâo Federal de 1988, ao prever o direito ao meio ambiente ecologicamente equilibrado, trata do Estudo Prévio de Impacto Ambiental (EPIA) como um dos instrumentos para garantir a efetividade desse direito. O EPIA ou EIA é exigível sempre que a obra ou atividade a ser instalada possa causar significativos danos ou degradaçáo do meio ambiente.

Com a interpretaçăo sistêmica dos direitos sociais, ambientais e culturais previstos na Constituiçâo Federal, o EPIA deveria ser concebido como instrumento de prevençấo e mitigaçăo de danos socioambientais, sem distinçăo. Na prática, há uma visăo fragmentada, que separa as gentes da natureza, e tem reduzido a eficácia do EPIA e limitado a efetivaçâo de direitos. Mesmo assim, o EPIA é elemento prévio e indispensável à instalaçăo de grandes obras de geraçâo hidrelétrica.

Após a apresentaçăo dos estudos, é emitida a primeira licença, a licença prévia (LP), aprovando a localizaçáo do empreendimento, atestando a sua viabilidade ambiental e 
estabelecendo alguns requisitos e condicionantes que deverâo ser atendidos durante as próximas fases de implementaçăo. Para a emissăo da licença de instalaçăo (LI) sâo analisados os planos, programas e projetos, e o cumprimento das condicionantes previamente estabelecidas, podendo ser impostas novas condiçōes. Na sequência, a licença de operaçăo (LO) autoriza o funcionamento do empreendimento, desde que verificado o cumprimento das condicionantes das licenças anteriores, determinando, desde já, as regras e condiçôes a serem observadas durante a operaçấo. As licenças podem ser expedidas isoladas ou sucessivamente, mas nunca de forma parcial (CONAMA, 1997).

Os primeiros estudos acerca do Complexo Madeira foram apresentados por Furnas Centrais Elétricas, em 2003. O Termo de Referência do Projeto para a realizaçâo do Estudo de Impacto Ambiental foi assinado no ano seguinte. Furnas, autorizada pela ANEEL a realizar os estudos de viabilidade do empreendimento junto à Odebrecht, contestou itens basilares do Termo de Referência: alegou a impossibilidade de diagnosticar os impactos em toda a bacia do rio Madeira e sobre o estado do Amazonas; e requisitou que o estudo sobre as eclusas, bem como sobre as linhas de transmissâo fossem desenvolvidos posteriormente. Todas as solicitaçōes foram atendidas (IBAMA, 2004).

O EIA/RIMA apresentado por Furnas e Odebrecht, e que contou com a consultoria da empresa Leme Engenharia Ltda., nâo cumpriu integralmente com o disposto no Termo de Referência, o que năo representou obstáculo para ser aceito para análise pelo IBAMA - o órgáo ambiental entendeu que eles poderiam ser complementados durante o processo (IBAMA, 2005). De acordo com o Parecer Técnico n. 133/2005, o Estudo "náo deixou claro se foi considerada na avaliaçâo dos impactos a existência de outros empreendimentos, existentes ou planejados. Em especial o impacto da ampliaçáo da hidrovia do rio Madeira (...)" (IBAMA, 2005, p. 02). Além disso, havia ausências nos estudos sobre o meio físico e biótico nas áreas de influência direta e indireta, como os corredores ecológicos na bacia hidrográfica e o resgate da fauna (IBAMA, 2005, p. 02). Sobre a linha de transmissăo, o IBAMA se contentou com as informaçōes apresentadas, "relativas às características físico-bióticas e socioeconômicas da regiâo possível para implantaçăo das LTs do sistema de transmissăo associado aos AHEs Jirau e Santo Antônio, interligando-os a Cuiabá" (IBAMA, 2005, p. 08)

Na análise preliminar do EIA/RIMA apresentado por Furnas e Odebrecht, o IBAMA emitiu a Informaçâo Técnica n. 12/2006, afirmando a necessidade de complementaçâo dos estudos, quanto aos meios físico, biótico e socioeconômico (IBAMA, 2006a). Em junho do mesmo ano, na Informaçáo Técnica n. 08/2006, o órgáo concluiu que as complementaçóes feitas nos quatro meses năo eram suficientes, e que alguns itens sequer haviam sido atendidos, por exemplo: a revisâo e detalhamento quanto à dinâmica de utilizaçâo das várzeas na área entre o remanso da UHE de Jirau e a jusante da UHE de Santo Antônio, do impacto das perdas de áreas naturais de lazer (praias, cachoeiras e igarapés) que continuou subestimado, os procedimentos administrativos quanto à área tombada da Estrada de Ferro Madeira-Mamoré, a necessidade de readequaçăo dos Programas Ambientais e de aprofundamento do estudo da ictiofauna e da remobilizaçăo de mercúrio (IBAMA, 2006b).

Em setembro de 2006, apesar de năo sanados ainda alguns problemas verificados no estudo, como a questăo da área tombada da Estrada de Ferro Madeira-Mamoré e do acúmulo de sedimentos, o IBAMA autorizou que o mesmo fosse disponibilizado para a sociedade, para a convocaçăo das audiências (IBAMA, 2006c). O Ministério Público Federal 
(MPF) e o Ministério Público Estadual (MPE) de Rondônia ajuizaram a primeira açăo civil pública (ACP) contra o Complexo do Madeira, alegando que as audiências marcadas nâo haviam sido suficientemente divulgadas e que o EIA/RIMA năo estava disponível em tempo hábil para a consulta pela sociedade. Nos autos do processo n. 2006.41.00.0048441, o Juízo Federal da $3^{a}$ Vara emitiu sentença afirmando que năo houve violaçăo ao princípio da publicidade (BRASIL, 2009). As audiências foram realizadas no começo de novembro no município de Porto Velho e no distrito de Jaci-Paraná e no final do mesmo mês nos distritos de Abuná e Mutum-Paraná.

Após a realizaçăo das quatro audiências públicas, de duas vistorias técnicas - uma realizada na época da seca e outra durante a cheia, de documentos recebidos pelo durante as audiências e de parecer técnico de hidrólogo contratado pelo IBAMA, o órgáo ambiental emitiu o parecer mais emblemático no que concerne às barragens do Madeira. Assinado pela Coordenadoria de Licenciamento, o Parecer Técnico n. 014/2007 data de março de 2007. Nele săo mencionadas todas as inconsistências verificadas pelos técnicos do IBAMA no EIA/RIMA produzido pelo consórcio (IBAMA, 2007a).

No documento săo levantados sete pontos principais a serem observados: a área de influência direta das barragens, que no EIA/RIMA havia sido considerada apenas como a parte da bacia localizada em território nacional, sem a dimensâo correta dos processos hidrossedimentológicos no rio Madeira (possibilidade de assoreamento dos reservatórios e agravamento dos efeitos de remanso); os impactos sobre a ictiofauna, especialmente com a supressâo das corredeiras e o impacto no fluxo migratório dos peixes; a extensâo de impactos diretos à Bolívia e ao Peru, năo mencionados nos estudos; a remobilizaçâo do mercúrio, que apresenta riscos desconhecidos de metilação do $\mathrm{Hg}$, danoso à saúde humana; a proliferaçăo da malária, que encontra no EIA/RIMA propostas frágeis ou até ilusórias de combate; a explosâo demográfica, subdimensionada para um aumento de aproximadamente 54.343 pessoas; por fim, o parecer trata da necessidade de integraçăo da área de influência com fauna e flora, considerando que a vegetaçâo dos pedrais era única e associada à dinâmica do rio, e servia também como alimento à ictiofauna (IBAMA, 2007a).

Ainda, a ausência de confiabilidade e exatidâo das informaçôes já mencionadas deveria levar a uma reestruturaçăo dos impactos e, consequentemente, à inclusăo de comunidades nâo previstas no diagnóstico inicial realizado pelo consórcio: os assentamentos da reforma agrária Joana D'Arc I, II e III; as comunidades ribeirinhas identificadas nas audiências públicas e no relatório protocolado pelo MPE-RO, como Porto Seguro e Engenho Velho; a Terra Indígena Jacareúba/Katawixi, no Estado do Amazonas; os povos indígenas Kaxarari, na regiăo de Extrema; os indígenas sem contato do igarapé Karipuninha e outros povos presentes na real área de influência (direta ou indireta), além da identificaçăo e caracterizaçăo das pessoas que sobreviviam da atividade garimpeira. Seria necessária ainda a incorporaçâo das áreas a jusante como potencialmente impactadas, para a caracterizaçăo destes impactos e as medidas de mitigaçăo cabíveis (IBAMA, 2007a).

O Diretor de Licenciamento à época, Luiz Felippe Kunz Júnior, năo acolheu o parecer e solicitou a revisăo de suas conclusôes, questionando a realizaçăo de novo EIA, e propondo, em seu lugar, a complementaçăo dos estudos e a manifestaçáo de especialistas de notório saber. A Procuradoria Geral do IBAMA se manifestou corroborando com 
a decisăo do Diretor de Licenciamento, mas destacou que caso fosse verificado impacto para além das fronteiras, deveria haver negociaçăo e participaçăo dos países vizinhos, e que as licenças prévias somente poderiam ser concedidas quando todas as dúvidas suscitadas pelos técnicos fossem superadas (IBAMA, 2007b). Assim, o IBAMA elaborou alguns quesitos para a complementaçăo dos estudos, em três diferentes áreas: com relaçăo aos sedimentos, à ictiofauna e ao mercúrio (IBAMA, 2007b).

A possibilidade de sedimentaçăo preocupava o Governo Federal, já que, além dos impactos socioambientais iminentes, poderia limitar a eficiência e o tempo de duraçáo das barragens, colocando um fim prematuro na energia elétrica gerada no rio Madeira. Por isso, o MME, com recursos do Banco Mundial, havia contratado previamente um especialista internacional no tema, Sultan Alam. O parecer elaborado pelo consultor, em janeiro de 2007, foi alvo de controvérsias. No Ofício n. 270/2007 (IBAMA, 2007c), o entâo Diretor de Licenciamento Ambiental do IBAMA, Valter Muchagata, solicita um posicionamento do Ministério de Minas e Energia quanto à proposiçấo do consultor, que afirma ser:

(...) de forte recomendaçăo de alteraçôes importantes no conceito e layout do projeto que segundo ele permitiriam a melhoria do conceito de projeto, economia de custo e reduçăo do tempo de construçăo podendo diminuir em 1 (um) Km a largura total da barragem, uma vez que mudanças no arranjo das usinas podem trazer reflexos ambientais. $O$ estudo realizado pelo consultor Sultan Alam diverge em metodologia e prognóstico do Estudo de Impacto Ambiental (...) (IBAMA, 2007c).

Na resposta ao ofício do IBAMA, o Secretário de Planejamento e Desenvolvimento Energético do MME, Márcio Pereira Zimmermann, confirma que as recomendaçóes do consultor poderiam acarretar economia no custo e reduçáo no tempo de construçáo da usina de Santo Antônio, e que esse projeto adicional aumentaria as alternativas aos interessados em participar do leilăo, mas que o detalhamento e otimizaçăo do projeto seriam efetuados somente na fase de projeto básico, após o leiláo. No entanto, nega a divergência apontada na metodologia e no prognóstico constantes no EIA e no parecer do consultor (MME, 2007).

Em reuniăo com outros especialistas no tema, representantes do MMA e do IBAMA, em março de 2007, foi elaborada uma nota técnica, que subsidiou o consórcio nas respostas dos quesitos elaborados pelo IBAMA. Portanto, as respostas aos quesitos náo foram elaboradas pelos especialistas, mas por Furnas e Odebrecht, concluindo que: "năo é imprescindível um conhecimento detalhado da origem dos sedimentos do rio madeira nesta fase de licenciamento prévio" (IBAMA, 2007b).

Em junho do mesmo ano, o consultor Carlos Eduardo Moreti Tucci, apresentou, a pedido do IBAMA, uma análise do EIA e de todos os demais estudos hidrossedimentológicos elaborados até entăo. O consultor concluiu que o EIA năo examinou, no âmbito da bacia hidrográfica, "se a tendência de evoluçăo do uso do solo poderia alterar de forma significativa a produçáo de sedimentos no local de interesse" e que "os documentos apresentados năo avaliaram os potenciais impactos sobre o trecho de jusante". De acordo com o consultor, o EIA apenas relata que a retençāo no reservatório seria mínima e que, por isso, năo deveria provocar grandes alteraçóes no trecho à jusante (IBAMA, 2007b).

Quanto à ictiofauna, a Gerência de Gestâo de Recursos Pesqueiros do Ministério do Meio Ambiente se manifestou sobre as respostas do consórcio, constatando que 
alguns questionamentos nâo foram plenamente atendidos ou náo foram respondidos, em especial quanto à possibilidade de sucesso do Sistema de Transposiçáo de Peixes, as consequências de mistura de populaçôes de peixes e o impacto no estoque pesqueiro e na conservaçăo; quanto ao impacto da barragem quanto à descida nas diferentes fases de espécies da ictiofauna; e quanto à possibilidade de espécies endêmicas virem ou nâo a ser extintas (IBAMA, 2007b).

Quanto ao mercúrio, foram analisados estudos de pesquisadores do Instituto Nacional de Pesquisa da Amazônia (INPA) sobre a contaminaçâo no reservatório da usina hidrelétrica de Balbina, entre os anos de 1992 e 2003 . O parecer elaborado pelos pesquisadores Bruce Forsberg e Alexandre Kemenes indica a ausência de itens fundamentais no EIA/RIMA, como o monitoramento dos níveis de mercúrio e programa de orientaçâo alimentar, para reduzir a carga diária de consumo (IBAMA, 2007b).

Apesar disso, em reuniâo do MMA, a conclusâo foi de que "os questionamentos e riscos sobre o mercúrio abordados náo se caracterizam como fatores de inviabilidade do empreendimento proposto" e que os "impactos das hidrelétricas no rio Madeira e adjacências na relaçăo mercúrio e saúde humana eram passíveis de serem prevenidos, monitorados e mitigados" (IBAMA, 2007b).

Em Parecer Técnico Conclusivo, o Diretor de Licenciamento finalmente alega que "năo se está autorizando açōes com impacto ambiental, mas permitindo que se formule projetos otimizados". É assim que, ao constatar que as medidas indicadas no Parecer n. 14/2007, da COHID/DILIC, foram "aceitas e incorporadas em grande parte", defende que a licença prévia pode ser emitida (IBAMA, 2007d).

Em março de 2007, o MPF ingressou com nova ACP, distribuída por dependência aos autos do processo n. 2006.41.00.004844-1, que tem no pólo passivo Furnas, Odebrecht e o IBAMA, para interromper todo e qualquer ato em relaçăo ao procedimento de licenciamento ambiental, alegando afronta aos princípios da legalidade e da probidade administrativa (BRASIL, 2007). Mesmo assim, em julho de 2007 a licença prévia (LP) foi concedida, assinada por presidente interino do IBAMA. A LP apresentava 33 condicionantes específicas, tratando da questăo dos sedimentos, que deveria ser mitigada no projeto executivo, da ictiofauna - sistema de transposiçáo dos peixes e centro de reproduçáo, do resgate da fauna, dos programas ambientais e sociais, dentre eles, o Programa de Apoio às Comunidades Indígenas, que deveria contemplar as recomendaçôes elaboradas pela FUNAI (IBAMA, 2007e).

As demais licenças foram sendo emitidas à revelia do cumprimento das condicionantes, que se acumularam. A licença de instalaçâo de Santo Antônio, emitida em agosto de 2008 para o consórcio formado por Furnas e Odebrecht, Madeira Energia S.A. (MESA), vencedor do leilăo, possui 48 condicionantes específicas. Dentre elas, repete-se a necessidade de inclusấo, no projeto executivo, de otimizaçấo da vazâo de sedimentos, larvas e ovos pelas turbinas e vertedouros (IBAMA, 2008a).

A energia média prevista era de 1.973 megawatts, com a cota em $70 \mathrm{~m}$, conforme o Contrato de Concessăo n. 001/2008-MME-UHE firmado com a Uniăo. Cinco dias após a emissâo da licença, houve uma retificaçâo, alterando a energia média para 2.200,13 megawatts (IBAMA, 2008b). Posteriormente, a Santo Antônio solicitou à ANEEL o aumento do nível de água máximo de operaçăo para a cota de 70,5 metros, alegando que os marcos utilizados haviam sido redefinidos pelo IBGE, em outubro de 2009. Sem a realizaçăo de 
novos estudos de impacto ambiental e novas audiências públicas, a ANEEL firma um aditivo aprovando a alteraçáo da cota.

No fim do mesmo ano ocorreu o primeiro desastre pós-barragens do Madeira, durante a construçáo das ensecadeiras: onze toneladas de peixes de diversas espécies apareceram mortos nas margens do rio, justamente durante o período do defeso. Esse fato originou a abertura de um processo de crime ambiental e multa pelo IBAMA e a instauraçăo de um inquérito civil público (ICP) pelo Ministério Público Federal, que resultou na celebraçâo de termo de ajustamento de conduta (TAC), em que a Santo Antônio Energia S.A. se comprometeu a apresentar um projeto de reposiçăo de 150 mil peixes (MPF, 2010).

A UHE de Jirau nâo está localizada na cachoeira de mesmo nome. Isto porque o local para a construçâo da barragem foi modificado pelo consórcio para uma distância de nove quilômetros do local original, previsto nos estudos e na licença prévia, o que gerou o ajuizamento de outra ACP pelo MPF e MPE (BRASIL, 2008).

Mesmo assim, uma licença de instalaçăo parcial foi concedida em novembro de 2008 (IBAMA, 2008c). Parcial porque possuía como objeto apenas a construçăo do canteiro de obras, em desacordo com as normas ambientais, que năo permitem esse fracionamento. A licença parcial foi suspensa por uma medida liminar da $3^{a}$ Vara da Justiça Federal de Rondônia. A licença de instalaçăo do empreendimento foi emitida em junho de 2009, com 54 condicionantes específicas, tais como: a otimizaçăo da vazâo dos sedimentos; a apresentaçâo da mancha de inundaçâo do reservatório e os efeitos de remanso, sobretudo o limite do reservatório no distrito de Abuná; a reforma de todos os programas ambientais vinculados com essa área de inundaçăo do reservatório e remanso; a formalizaçâo dos compromissos assumidos em relaçâo ao Programa de Açóes à Jusante; o atendimento às recomendaçôes da FUNAI e ao Plano Emergencial de Proteçâo e Vigilância e Terras Indígenas do Complexo Madeira; a reformulaçâo do Programa de Monitoramento e Apoio à Pesca e execuçăo dos demais programas sociais e ambientais (IBAMA, 2009).

Passado o leilăo, o consultor Sultan Alam foi novamente contratado, desta vez a pedido do consórcio responsável pela UHE de Jirau, para apresentar parecer sobre a alteraçâo da localizaçâo da barragem. Sultan Alam aponta riscos de perda das turbinas por conta dos sedimentos, sobre os quais as informaçôes colhidas até entâo eram insuficientes (MONTEIRO, 2011).

Mas a entrada em operaçăo de Jirau foi autorizada em outubro de 2012, com sua localizaçăo na Ilha do Padre, na cota 90m (IBAMA, 2012a). A licença de operaçăo previa um conjunto de 44 turbinas, alteradas pela primeira retificaçâo (novembro/2012) para 50 turbinas (IBAMA, 2012b). Em julho de 2013 houve nova retificaçăo, apenas para definir o valor de compensaçăo ambiental, que năo havia sido arbitrado anteriormente (IBAMA, 2013). O consórcio responsável pela UHE de Jirau se denomina Energia Sustentável do Brasil (ESBR) e é composto pelas controladas da Eletrobrás, Chesf e Eletrosul, pela GDF Suez S.A. (hoje denominada ENGIE), transnacional francesa do ramo energético, e pela Mitsui \& Co., transnacional japonesa que investe em ramos diversificados, dentre eles, energia e minérios (ESBR, 2017).

A licença de operaçăo de Jirau reitera a necessidade de monitoramento da qualidade da água, já levantada na licença de instalaçăo, especialmente nos rios Cotia, Mutum Paraná, bolsăo do Mutum Paraná, Jirau, Săo Lourenço e outro tributário do Madeira 
náo identificado, próximo ao barramento. Requer também o monitoramento da água no ponto de captaçáo da vila construída de Nova Mutum Paraná. Assim como na barragem de Santo Antônio, a licença veta o rebaixamento do nível operacional para fins de descarga de sedimentos, afirmando que o nível de água normal do reservatório deve acompanhar as variaçôes naturais do rio Madeira. No âmbito do Programa de Remanejamento da Populaçăo Atingida, o IBAMA afirma que as casas de Nova Mutum Paraná, a serem desocupadas pelos funcionários da ESBR, deverăo ser doadas à Prefeitura Municipal de Porto Velho ou, caso esta náo receba, deverá "ser dada destinaçăo socialmente viável e/ ou desmobilizaçấo das estruturas, aliada as atividades de recuperaçăo de áreas degradadas (...)" (IBAMA, 2013, p. 06).

A licença de operaçăo de Santo Antônio, de setembro de 2011, além de exigir a continuidade dos programas já previstos no Plano Básico Ambiental (PBA) e também listados na Licença de Instalaçáo, conta com outras 34 condicionantes específicas. No âmbito do Programa de Monitoramento Hidrossedimentológico, determina a apresentaçăo de propostas para o monitoramento de potenciais processos erosivos à jusante da usina. Ocorrendo as erosōes, deveriam ser adotadas açōes mitigatórias/compensatórias compartilhadas com a UHE de Jirau. O monitoramento da qualidade da água é solicitado para os pontos de captaçáo de água da cidade de Porto Velho, além do monitoramento intensivo nos rios Jaci-Paraná, Jatuarana I e Teotônio. O Sistema de Transposiçáo de Peixes também é citado, devendo permanecer ativo durante toda a vida útil do empreendimento. Devem ser implementados o Subprograma de Monitoramento da Atividade Pesqueira e o Subprograma de Recomposiçăo e Compensaçăo da Atividade Pesqueira (IBAMA, 2011). Até entăo, a capacidade instalada da usina era de 3.150 megawatts, contando com o funcionamento de 44 turbinas do tipo bulbo, na cota de 70,5m. O consórcio empreendedor se denomina Santo Antônio Energia S.A., tendo em sua composiçăo: Furnas Centrais Elétricas (controlada pela Eletrobrás), Caixa FIP Amazônia Energia (fundo de investimento), Odebrecht Energia do Brasil, SAAG Investimentos (tem como acionista majoritário a Andrade Gutierrez Participaçóes S.A.) e CEMIG Geraçăo e Transmissăo (empresa mista, controlada pelo governo do estado de Minas Gerais) (SAE, 2016).

Apesar da tragédia anunciada ocorrida com a grande cheia de 2014, em maio de 2016 a LO da UHE de Santo Antônio foi renovada, aumentando a capacidade instalada da usina para 3.568 megawatts, com 50 turbinas e validade por um período de 10 anos. $\mathrm{Na}$ renovaçấo, a partir da constataçăo de diversos problemas com a entrada em operaçấo da usina, o IBAMA estabeleceu novas condicionantes, envolvendo o monitoramento hidrossedimentológico e do lençol freático, o monitoramento social e econômico, e o Sistema de Transposiçăo de Peixes (STP), que năo vinha se mostrando efetivo (IBAMA, 2016).

A cota de 70,5m só voltaria a ser alterada em dezembro do mesmo ano, por solicitaçăo do consórcio, aumentando para 71,3m, para o funcionamento das turbinas adicionais. No entanto, o aumento foi sustado a partir de pedido do Ministério Público Federal e do Ministério Público Estadual em Rondônia, formulado à Justiça Federal, para o cumprimento imediato de duas decisóes liminares que proibiam o IBAMA de emitir licença para o aumento do reservatório da UHE Santo Antônio. Nas duas açôes que tratam da elevaçăo da cota, os procuradores alegam o năo cumprimento das condicionantes pela Santo Antônio Energia, a ausência de plano de segurança da barragem, tanto para o reservatório antigo quanto para o aumento, e a inexistência de audiências públicas para a 
discussăo dos impactos com as populaçōes atingidas (BRASIL, 2014a e BRASIL, 2014b) Além disso, há liminar concedida em açăo civil pública determinando que o EIA de Santo Antônio e Jirau seja refeito, considerando os impactos decorrentes da cheia de 2014, o que ainda năo ocorreu (BRASIL, 2014c).

Os impactos e violaçōes de direitos causados pela construçâo das duas hidrelétricas no rio Madeira năo tardaram a aparecer. Entre a expropriaçăo das terras, a exclusâo de camponeses, indígenas e ribeirinhos de todo o processo de licenciamento ambiental, o inchaço populacional urbano nos municípios do entorno, o assédio e a violência sexual, inclusive contra crianças e adolescentes, todos estes impactos podem ser verificados no Relatório da Plataforma Brasileira de Direitos Humanos, Econômicos, Sociais e Ambientais (Plataforma DhESCA Brasil), que realizou uma missăo com a finalidade de averiguar as violaçôes de direitos humanos ambientais no Complexo Madeira (PLATAFORMA DHESCA BRASIL, 2008).

O processo de licenciamento ambiental deveria preservar direitos coletivos, que năo săo apenas das populaçóes tradicionais, mas da sociedade como um todo, que possui direitos difusos ao meio ambiente equilibrado. Apesar disso, ele vem sendo guiado por decisóes que visam interesses individuais. Ao invés de se adotar medidas para o necessário fortalecimento do licenciamento, o que se tem visto săo propostas para o seu desmantelamento, como o Projeto de Lei n. 654, de 2015, em tramitaçăo no Senado (BRASIL, 2015) e o PL 3729, de 2004, que tramita na Câmara dos Deputados em regime de urgência (BRASIL, 2004).

O PL 654 dispóe sobre um licenciamento especial para empreendimentos de infraestrutura considerados estratégicos e de interesse nacional. Na prática, isto quer dizer que a construçâo de empreendimentos como hidrelétricas ou hidrovias seriam ainda mais céleres, com a emissâo de uma única licença ambiental integrada (BRASIL, 2015).

O PL 3729 propóe uma Lei Geral do Licenciamento Ambiental, que na forma como vem sendo construída, abre brechas para a dispensa de licenciamento em diversos casos, em atividades agropecuárias, obras de melhorias, modernizaçăo e manutençáo de empreendimentos de infraestrutura de transporte, entre outros (BRASIL, 2004), além de restringir os direitos de povos e comunidades tradicionais, limitando a participaçáo de órgâos como a Fundaçâo Nacional do Índio (FUNAI), a Fundaçâo Cultural Palmares (FCP) e o Instituto Chico Mendes de Conservaçăo da Biodiversidade (ICMBio) nos processos de licenciamento.

O que ambos projetos preveem sâo retrocessos na legislaçâo socioambiental. Enquanto isso, os povos resistem por avanços, já que săo invisibilizados frente ao licenciamento de grandes obras.

\section{CONSIDERAÇÕES FINAIS}

O conturbado processo de licenciamento ambiental desrespeitou as normas que deveriam regê-lo, e demonstrou uma permissividade do Estado com a finalidade de agilizar o andamento das obras. Os direitos da populaçăo urbana do município de Porto Velho năo foram respeitados, dada a inexistência de informaçăo prévia e de qualidade à sociedade, e as alteraçôes substanciais em ambos os projetos sem qualquer debate público. 
A natureza e as populaçóes tradicionais, sempre relegadas a um segundo plano, sequer foram devidamente consideradas nos estudos de impacto ambiental.

Diante de tudo o que foi exposto, é possível concluir que o estudo prévio de impacto ambiental e o licenciamento ambiental das barragens construídas no Rio Madeira năo atenderam aos pressupostos mínimos legais. Em alguns momentos, pela estrutura deficitária dos órgăos que deveriam acompanhar o empreendimento, em outros, pela própria forma como os procedimentos foram conduzidos pelas autoridades responsáveis.

Isso vem ocorrendo nâo apenas no Rio Madeira, mas na construçâo de barragens em todo o país, particularmente nos rios da Amazônia. O licenciamento deveria analisar e obrigar à reparaçấo dos danos à natureza e às gentes, mas vem sendo erroneamente interpretado e executado. Com isso, os impactos que deveriam ter sido mitigados nas fases anteriores à construçâo e operaçăo das barragens, foram multiplicados. Ao olhar para as beiras do Madeira hoje năo há como negar que o processo de licenciamento foi falho e que o modelo energético em curso está fadado a um fim próximo - ou ao fim das gentes de toda a Amazônia.

O licenciamento ambiental está inserido no contexto do atual modelo energético e é pautado pelas decisôes político-econômicas que conduzem o ritmo do país: em determinados momentos históricos percebe-se um maior investimento em grandes obras, chegando às parcerias entre Estado e empresas privadas, com grande atuaçăo transnacional. A garantia de direitos para as populaçóes atingidas pelos empreendimentos também dependerá do posicionamento do governo e da atuaçăo de seus órgăos ambientais, além, por certo, das decisôes do Poder Judiciário.

O cenário atual năo é animador para a parcela trabalhadora da populaçăo brasileira, com a possibilidade de diminuiçáo de postos de trabalho e encarecimento da tarifa de energia elétrica a partir da proposta de privatizaçăo da Eletrobrás. Com um menor controle e financiamento público, há uma consequente diminuiçấo na construçăo de novos empreendimentos de geraçăo de energia hidrelétrica. No entanto, com a possível flexibilizaçăo do licenciamento ambiental, a tendência é que os novos empreendimentos representem uma menor segurança à populaçăo no entorno, uma maior violaçăo de direitos de povos e comunidades tradicionais e um maior impacto à natureza, que atinge a todas e todos, indiscriminadamente.

No último período tem-se verificado um retrocesso generalizado de direitos. Ao contrário, é fundamental que os direitos das populaçōes atingidas estejam devidamente regulamentados e que o processo de licenciamento ambiental, assim como os órgâos responsáveis por conduzi-lo, seja fortalecido, sob pena de se repetirem os mesmos erros já acumulados por outras tantas barragens na Amazônia, inclusive Santo Antônio e Jirau. Como demonstrado, somente com o recrudescimento da democracia é possível avançar nas questôes socioambientais. 
1 As participaçôes dos grupos Light e Amforp se espalharam por quase todos os países latino-americanos, desde a Patagônia até o Rio Bravo: Argentina, Bolívia, Chile, Cuba, México, Nicarágua, Uruguai, etc.

${ }^{2}$ A Revoluçáo de 1930 foi um movimento armado que teve como um de seus principais objetivos o rompimento com a política agroexportadora exercida pelas oligarquias. Com o movimento, teve início a fase industrial do capitalismo brasileiro, e foram executadas medidas de caráter reformista, como o estabelecimento da legislaçâo trabalhista.

${ }^{3}$ Até entăo, a moeda nacional seguia o padrăo ouro, ou seja, o ouro era internacionalmente reconhecido como indexador econômico. 0 Decreto n. 23.501/1933 determinou que os valores de serviços de energia elétrica năo fossem mais regulados a partir do ouro.

${ }^{4}$ O PNE náo chegou a ser formalmente aprovado pelo Legislativo, mas suas premissas foram fundamentais à expansăo da indústria de energia elétrica no Brasil.

${ }^{5}$ Em mensagem ao Congresso Nacional, o presidente Getúlio Vargas afirmou que: “É uma característica da época atual o desinteresse do capital privado para serviços de utilidade pública. Apesar de lucrativas, as grandes empresas năo têm atraído novos capitais em proporçáo conveniente e vêm retardando seu ritmo de expansăo para năo ultrapassar as possibilidades de autofinanciamento ou de obtençăo de créditos com o apoio dos governos (...). É indispensável, por isto que o governo assuma uma posiçăo ativa em face do problema da criaçáo de novos recursos de energia elétrica (...), que assuma a responsabilidade de construir sistemas elétricos onde sua falta representa maiores deficiências" (DRAIBE, 1985, p. 201).

${ }^{6}$ O golpe de 1964 acontece no contexto histórico da Guerra Fria. O Brasil alinhou-se aos Estados Unidos, com a política de segurança nacional, pretendendo situar-se como "potência emergente". A divisăo bipolar capitalismo versus comunismo era a base da doutrina de segurança nacional, que combatia a subversăo prezando pela "segurança coletiva". Assim, năo comportava o conflito, a divergência. Os pilares políticos da época săo, portanto, segurança e desenvolvimento.

${ }^{7}$ Com a fragmentaçáo entre os segmentos, a Eletrosul (transmissăo) permaneceu sob o controle da Eletrobrás, mas a geraçấo, repassada para a Gerasul, foi alienada a empresas privadas (atualmente pertence ao grupo Tractebel).

${ }^{8}$ Um exemplo é o Programa Luz para Todos, de universalizaçăo do acesso à energia elétrica.

${ }^{9} \mathrm{~A}$ ANP, por exemplo, interrompeu os leilōes de blocos por longo período, especialmente o de Libra no pré-sal.

${ }^{10}$ Há em discussăo um projeto de lei para a extinçăo da Área de Proteçăo Ambiental (APA) de Campos de Manicoré, e a diminuiçăo do Parque Nacional (Parna) de Acari, da Reserva Biológica (Rebio) de Manicoré e das Florestas Nacionais (Flonas) de Urupadi e Aripuaná, uma área protegida total de 2,6 milhóes de hectares que seria reduzida para 1,6 milhăo (ISA, 2017).

${ }^{11}$ A Lei n. 13.334, de 13 de setembro de 2016, criou o Programa de Parcerias de Investimento - PPI que, em sua primeira reuniăo, anunciou o Programa Crescer, com um pacote de trinta e quatro projetos destinados a concessóes e privatizaçóes, dentre aeroportos, rodovias, ferrovias, campos de petróleo e obras de saneamento. No governo Bolsonaro, em 2018, foi criada ainda a Secretaria Especial de Desestatizaçăo, Desinvestimento e Mercados, vinculada ao Ministério da Economia.

12 Interessante notar a redaçáo do Decreto n. 2.655, de 02 de julho de 1998, que regulamenta o Mercado 
Atacadista de Energia Elétrica, e afirma que: "As atividades de geraçâo e de comercializaçāo de energia elétrica, inclusive sua importaçăo e exportaçâo, deverâo ser exercidas em caráter competitivo, assegurado aos agentes econômicos interessados livre acesso aos sistemas de transmissâo e distribuiçấo, mediante o pagamento dos encargos correspondentes e nas condiçôes gerais estabelecidas pela ANEEL" (artigo $2^{\circ}$ ).

${ }^{13}$ Mesmo as estatais do setor sâo constituídas, em parte, por capital privado: $60 \%$ da Eletrobrás, $80 \%$ da CEMIG e $65 \%$ da Cesp.

${ }^{14}$ Cf. MINISTÉRIO DE MINAS E ENERGIA - MME (Brasil). Contrato de concessăo $\mathbf{n}^{\circ}$ 001/2008-MME-UHE Santo Antônio. Processo n 48500.001273/2008-22. Brasília: MME, 2008

${ }^{15}$ O preço do custo de produçáo é o custo de produção próprio da mercadoria mais o lucro médio do capital investido.

${ }^{16}$ Bertha Becker (2009, p. 34) trata da Amazônia nesse período como "fronteira do capital natural".

17 Ueki foi nomeado ministro das Minas e Energia no dia 15 de março de 1974 pelo presidente Ernesto Geisel e permaneceu no cargo até o fim do mandato em 1979.

${ }^{18}$ Com 49\% de participaçăo de investidores japoneses.

${ }^{19} \mathrm{O}$ interesse na exploraçâo hidrelétrica do rio Madeira é ainda mais antigo: em 1984, já havia sido realizado um estudo de pré-inventário pela CNEC, uma das principais empresas na elaboraçâo de projetos durante a ditadura militar no país.

${ }^{20}$ Lei n. 6.938/1981, artigo 10.

${ }^{21}$ O RIMA se apresenta como uma síntese, elaborada a partir do EIA.

${ }^{22}$ A justificativa do Parecer para a ausência de EIA/RIMA das linhas de transmissăo é de que: "O Termo de Referência emitido inicialmente solicitou que, com relaçâo ao Sistema de Transmissâo Associado, fosse apresentada uma avaliaçăo com a abordagem e profundidade de um EIA/RIMA. Em correspondência (GA.I.E.289.2004) enviada em 17.11.2004, Furnas ponderou a dificuldade de atender ao especificado, sugerindo que as informaçóes concernentes a esse item fossem inseridas no EIA/RIMA considerando o corredor de passagem como foco" (IBAMA, 2005, p. 08).

${ }^{23}$ O IBAMA concordou em prorrogar a resoluçâo da questăo dos sedimentos, afirmando que: “Considerando as características intrínsecas dos fenômenos ligados aos sedimentos com explícita continuidade de seus estudos e monitoramentos, concluímos pela impossibilidade de extraçăo e apropriaçáo de novas informaçôes nesta fase, pelo atendimento à solicitaçăo de complementaçâo, nâo impedimento a disponibilizaçăo do EIA e convocaçăo das Audiências Públicas" (IBAMA, 2006c, p. 07)

${ }^{24}$ Com os dados atuais fornecidos pelo IBGE, calcula-se um aumento demográfico em torno de 141.874 pessoas, entre os anos de 2007 e 2016. Considerando que as obras foram iniciadas em 2008 e tiveram seu término em 2016, é possível que em alguns períodos a explosâo tenha se dado de forma mais significativa que em outros, e que a cidade já esteja experimentando a retirada de parte dos migrantes.

${ }^{25}$ Os consultores presentes eram José Galizia Tundisi (Instituto Internacional de Ecologia), Newton de Oliveira Carvalho (Universidade Federal do Mato Grosso do Sul) e Sultan Alam (International Hydropower Association).

${ }^{26}$ Os pesquisadores que contribuíram com as questōes sobre a ictiofauna foram: Jansen A. S. Zuanon (Instituto Nacional de Pesquisa da Amazônia), José Galizia Tundisi (Instituto Internacional de Ecologia), Ângelo Antônio 
Agostinho (Fundaçáo Universidade Estadual de Maringá) e Domingo Rodrigues Fernandes.

${ }^{27}$ Foram realizadas mudanças frequentes nos cargos de presidência e diretorias do IBAMA à época da concessâo das primeiras licenças para as usinas hidrelétricas no rio Madeira, o que pode ser observado facilmente a partir da análise dos documentos emitidos pelo órgāo.

${ }^{28}$ O Ministério Público Federal e o Ministério Público do Estado de Rondônia ajuizaram ACP, em 25 de agosto de 2008, com pedido liminar contra a mudança de localizaçăo da usina de Jirau, no rio Madeira. A ANEEL, o IBAMA e o Consórcio Energia Sustentável do Brasil (Enersus), hoje ESBR, sâo os réus da açâo.

\section{REFERÊNCIAS}

ACOSTA, Alberto. Extrativismo e neoextrativismo: duas faces da mesma maldiçăo. Em: DILGER, Gerhard; LANG, Miriam; PEREIRA FILHO, Jorge (orgs.). Descolonizar o imaginário: debates sobre o pós-extrativismo e alternativas ao desenvolvimento. Traduzido por Igor Ojeda. Săo Paulo: Fundaçâo Rosa Luxemburgo, 2016.

AGÊNCIA NACIONAL DE ENERGIA ELÉTRICA - ANEEL (Brasil). Por dentro da conta de luz: informaçăo de utilidade pública. 7. ed. Brasília: ANEEL, 2016.

AGÊNCIA NACIONAL DE ENERGIA ELÉTRICA - ANEEL (Brasil). Atlas de energia elétrica do Brasil. 2. ed. Brasília: ANEEL, 2005.

ALMEIDA, Alfredo Wagner Berno de. A última grande fronteira amazônica: anotaçóes de preâmbulo. Em: ALMEIDA, Alfredo Wagner Berno de (org.). Conflitos sociais no “Complexo Madeira". Manaus: Projeto Nova Cartografia Social da Amazônia / UEA Ediçōes, 2009.

BECKER, Bertha Koiffmann. Amazônia: geopolítica na virada do III milênio. Rio de Janeiro: Garamond, 2009.

BERMANN, Célio. O projeto da Usina Hidrelétrica Belo Monte: a autocracia energética como paradigma. Novos Cadernos NAEA, Belém, v. 15, n. 1, p.5-23, jun. 2012. Núcleo de Altos Estudos Amazônicos. http://dx.doi.org/10.5801/s21797536. Disponível em: <http:// www.periodicos.ufpa.br/index.php/ncn/article/view/895>. Acesso em: 16 fev. 2017.

BERMANN, Célio. A crise ética e técnica do setor energético brasileiro. Entrevista especial com Célio Bermann. Instituto Humanitas Unisinos, fev. 2015. Entrevista concedida a Ricardo Machado. Disponível em <http://www.ihu.unisinos.br/entrevistas/ 539420-a-crise-etica- e-tecnica- do-setor- energetico-brasileiro- entrevista-especialcom-celio-bermann>. Acesso em: 16 fev. 2017.

BRASIL. Lei n $\mathbf{1 2 . 6 7 8}$, de 25 de junho de 2012. Dispóe sobre alteraçôes nos limites dos Parques Nacionais da Amazônia, dos Campos Amazônicos e Mapinguari, das Florestas Nacionais de Itaituba I, Itaituba II e do Crepori e da Área de Proteçăo Ambiental do Tapajós; altera a Lei no 12.249, de 11 de junho de 2010; e dá outras providências. Disponível em: <http://www.planalto.gov.br/ccivil_03/_Ato2011-2014/2012/Lei/L12678.htm〉. Acesso em: 16 fev. 2017. 
BRASIL. Lei n 6.938, de 31 de agosto de 1981. Dispóe sobre a Política Nacional do Meio Ambiente, seus fins e mecanismos de formulaçăo e aplicaçăo, e dá outras providências. Disponível em: 〈http://www.planalto.gov.br/ccivil_03/LEIS/L6938.htm〉. Acesso em: 16 fev. 2017

BRASIL. Lei $\mathbf{n}^{\mathbf{0}} \mathbf{9 . 0 7 4}$, de $\mathbf{7}$ de julho de $\mathbf{1 9 9 5}$. Estabelece normas para outorga e prorrogaçóes das concessōes e permissōes de serviços públicos e dá outras providências. Disponível em: 〈http://www.planalto.gov.br/ccivil_03/leis/L9074cons.htm>. Acesso em: 17 fev. 2017.

BRASIL. Tribunal Regional Federal (Primeira Regiăo). Terceira Vara Federal da Seçăo Judiciária do Estado de Rondônia. Autores: Ministério Público Federal e Ministério Público Estadual de Rondônia. Réus: Furnas Centrais Elétricas S.A. e Instituto Brasileiro do Meio Ambiente e Recursos Naturais - IBAMA. Autos n ${ }^{0}$ 2006.41.00.004844-1. Sentença em açăo civil pública. Juiz Federal Élcio Arruda. DJF, 22 dez. 2009.

BRASIL. Tribunal Regional Federal (Primeira Regiăo). Terceira Vara da Seçăo Judiciária do Estado de Rondônia. Açăo civil pública ambiental com pedido de provimento liminar. Autor: Ministério Público Federal. Réus: Furnas Centrais Elétricas S.A. e Instituto Brasileiro do Meio Ambiente e Recursos Naturais - IBAMA. Distribuiçáo por dependência aos autos $n^{\circ}$ 2006.41.00.004844-1. Porto Velho, RO, 12 de março de 2007.

BRASIL. Tribunal Regional Federal (Primeira Regiăo). Terceira Vara Federal da Seçâo Judiciária do Estado de Rondônia. Açăo civil pública ambiental. Autos $n^{\circ}$ 2008.41.00.005474-0. Autores: Ministério Público Federal e Ministério Público Estadual de Rondônia. Réus: Agência Nacional de Energia Elétrica - ANEEL, Instituto Brasileiro do Meio Ambiente e Recursos Naturais Renováveis - IBAMA e Consórcio Enersus - Energia Sustentável do Brasil S/A. Porto Velho, RO, 25 de agosto de 2008.

BRASIL. Tribunal Regional Federal (Primeira Regiăo). Quinta Vara Federal da Seçáo Judiciária do Estado de Rondônia. Decisăo liminar em açăo civil pública. Autos n $2427-$ 33.2014.4.01.4100. Autores: Ministério Público Federal, Ministério Público Estadual de Rondônia, Ordem dos Advogados do Brasil Seccional Rondônia, Defensoria Pública da Uniâo e Defensoria Pública do Estado de Rondônia. Réus: Instituto Brasileiro do Meio Ambiente e Recursos Naturais Renováveis - IBAMA, Santo Antônio Energia - SAE e Energia Sustentável do Brasil - ESBR. Juiz Federal Herculano Martins Nacif. Porto Velho, RO, 10 de março de 2014c.

BRASIL. Tribunal Regional Federal (Primeira Regiăo). Quinta Vara Federal da Seçăo Judiciária do Estado de Rondônia. Decisăo liminar em açăo civil pública. Autos $n^{\circ} 6888$ 19.2012.4.01.4100. Autores: Ministério Público Federal e Ministério Público Estadual de Rondônia. Réus: Instituto Brasileiro do Meio Ambiente e Recursos Naturais Renováveis - IBAMA e Santo Antônio Energia - SAE. Juiz Federal Herculano Martins Nacif. Porto Velho, RO, 05 de junho de 2014b.

BRASIL. Tribunal Regional Federal (Primeira Regiăo). Quinta Vara Federal da Seçâo Judiciária do Estado de Rondônia. Decisăo liminar em açăo civil pública. Autos n 1339 57.2014.4.01.4100. Autores: Ministério Público Federal e Ministério Público Estadual de 
Rondônia. Réus: Instituto Brasileiro do Meio Ambiente e Recursos Naturais Renováveis - IBAMA. Juiz Federal Herculano Martins Nacif. Porto Velho, RO, 06 de março de 2014a.

BRASIL. Projeto de Lei do Senado $\mathbf{n}^{\circ} \mathbf{6 5 4}$, de 2015. Dispôe sobre o procedimento de licenciamento ambiental especial para empreendimentos de infraestrutura considerados estratégicos e de interesse nacional. Disponível em: <http://www25.senado.leg.br/web/ atividade/materias/-/materia/123372>. 2015a. Acesso em: 17 fev. 2017.

BRASIL. Projeto de Lei $\mathbf{n}^{\circ}$ 3729, de 2004. Dispóe sobre o licenciamento ambiental, regulamenta o inciso IV do $\S 1^{\circ}$ do art. 225 da Constituiçăo Federal, e dá outras providências. Disponível em: <https://www.camara.leg.br/proposicoesWeb/fichadetramitacao?idProposicao=257161>. 2004. Acesso em: 15 out. 2019.

CÂMARA DE COMERCIALIZAÇĀO DE ENERGIA ELÉTRICA - CCEE. Onde atuamos. Setor Elétrico. Disponível em: 〈https://www.ccee.org.br〉. Acesso em: 16 fev. 2017.

CASTRO, Nivalde. 0 setor de energia elétrica no Brasil: a transiçâo da propriedade privada estrangeira para a propriedade pública (1945-1961). Dissertaçăo (Mestrado em Economia Industrial) - Instituto de Economia, Universidade Federal do Rio de Janeiro, Rio de Janeiro, 1985.

CONAMA. Resoluçăo n 279, de 27 de junho de 2001. Disponível em: <http://www.mma. gov.br/port/conama/res/res01/res27901.html>. Acesso em: 16 fev. 2017.

CONAMA. Resoluçăo n 237, de 19 de dezembro de 1997. Disponível em: <http://www. mma.gov.br/port/conama/res/res97/res23797.html>. Acesso em: 16 fev. 2017.

DRAIBE, Sônia Miriam. Rumos e metamorfoses: um estudo sobre a constituiçâo do Estado e as alternativas da industrializaçăo no Brasil 1930-1960. Rio de Janeiro: Paz e Terra, 1985.

ENERGIA SUSTENTÁVEL DO BRASIL [ESBR]. Sócios acionistas. Disponível em: <http:// www.energiasustentaveldobrasil.com.br/>. Acesso em: 16 fev. 2017.

FEARNSIDE, Philip M. Hidrelétricas na Amazônia brasileira: Questôes ambientais e sociais. pp. 289-315 Em: D. Floriani \& A.E. Hevia (Eds.). América Latina Sociedade e Meio Ambiente: Teorias, Retóricas e Conflitos em Desenvolvimento. Curitiba: Editora da Universidade Federal do Paraná, 2016. Disponível em: <http://philip.inpa.gov.br/publ livres/2016/Fearnside-Hidrel\%C3\%A9tricas_na_Amaz\%C3\%B4nia\%20BrasileiraUFPR-2016.pdf>. Acesso em: 16 fev. 2017.

FIESP - FEDERAÇĀO DAS INDÚSTRIAS DO ESTADO DE SĂO PAULO. Livre para crescer. Sáo Paulo: Cultura Editores Associados, 1990.

GONÇALVES JUNIOR, Dorival. Reformas na indústria elétrica brasileira: a disputa pelas 'fontes' e o controle dos excedentes. Tese (Doutorado em Energia) - Instituto de Eletrotécnica e Energia/Faculdade de Economia, Administraçăo e Ciências Contábeis/ Instituto de Física/Escola Politécnica - Universidade de Sáo Paulo, Sâo Paulo, 2007. 
IANNI, Octávio. Estado e planejamento econômico no Brasil. 6 ed. Rio de Janeiro: civilizaçăo brasileira, 1996.

INSTITUTO BRASILEIRO DO MEIO AMBIENTE E DOS RECURSOS NATURAIS RENOVÁVEIS [IBAMA]. Termo de Referência para elaboraçăo do estudo de impacto ambiental e o respectivo relatório de impacto ambiental - EIA/RIMA. Brasília, 2004.

INSTITUTO BRASILEIRO DO MEIO AMBIENTE E DOS RECURSOS NATURAIS RENOVÁVEIS [IBAMA]. Parecer Técnico n 133/2005 - COLIC-HID/CGLIC/DILIQ/ IBAMA. Brasília, 2005.

INSTITUTO BRASILEIRO DO MEIO AMBIENTE E DOS RECURSOS NATURAIS RENOVÁVEIS [IBAMA]. Informaçăo Técnica $n^{\circ}$ 12/2006 - COLIC-HID/CGLIC/DILIQ/ IBAMA. Brasília, 2006a.

INSTITUTO BRASILEIRO DO MEIO AMBIENTE E DOS RECURSOS NATURAIS RENOVÁVEIS [IBAMA]. Informaçăo Técnica $\mathbf{n}^{0}$ 08/2006 - COHID/CGENE/DILIC/ IBAMA. Brasília, 2006b.

INSTITUTO BRASILEIRO DO MEIO AMBIENTE E DOS RECURSOS NATURAIS RENOVÁVEIS [IBAMA]. Informaçăo Técnica $\mathbf{n}^{\mathbf{0}} \mathbf{3 4 / 2 0 0 6}$ - COHID/CGENE/DILIC/ IBAMA. Brasília, 2006c.

INSTITUTO BRASILEIRO DO MEIO AMBIENTE E DOS RECURSOS NATURAIS RENOVÁVEIS [IBAMA]. Parecer Técnico n 014/2007 - COHID/CGENE/DILIC/IBAMA. Brasília, 2007a.

INSTITUTO BRASILEIRO DO MEIO AMBIENTE E DOS RECURSOS NATURAIS RENOVÁVEIS [IBAMA]. Memorando n 379/2007 - DILIC/IBAMA. Brasília, 2007b.

INSTITUTO BRASILEIRO DO MEIO AMBIENTE E DOS RECURSOS NATURAIS RENOVÁVEIS [IBAMA]. Ofício n² 270/2007 - DILIC/IBAMA. Brasília, 2007c.

INSTITUTO BRASILEIRO DO MEIO AMBIENTE E DOS RECURSOS NATURAIS RENOVÁVEIS [IBAMA]. Parecer Técnico Conclusivo - DILIC/IBAMA. Brasília, 2007d.

INSTITUTO BRASILEIRO DO MEIO AMBIENTE E DOS RECURSOS NATURAIS RENOVÁVEIS [IBAMA]. Licença Prévia n²51/2007. Brasília, 2007e.

INSTITUTO BRASILEIRO DO MEIO AMBIENTE E DOS RECURSOS NATURAIS RENOVÁVEIS [IBAMA]. Licença de Instalaçăo $\mathbf{n}^{0}$ 540/2008. Brasília, 2008a.

INSTITUTO BRASILEIRO DO MEIO AMBIENTE E DOS RECURSOS NATURAIS RENOVÁVEIS [IBAMA]. Licença de Instalaçăo $n^{\circ}$ 540/2008 (Retificaçáo). Brasília, 2008b.

INSTITUTO BRASILEIRO DO MEIO AMBIENTE E DOS RECURSOS NATURAIS RENOVÁVEIS [IBAMA]. Licença de Instalaçâo $\mathbf{n}^{\circ}$ 563/2008. Brasília, 2008c. 
INSTITUTO BRASILEIRO DO MEIO AMBIENTE E DOS RECURSOS NATURAIS RENOVÁVEIS [IBAMA]. Licença de Instalaçăo n 621/2009. Brasília, 2009.

INSTITUTO BRASILEIRO DO MEIO AMBIENTE E DOS RECURSOS NATURAIS RENOVÁVEIS [IBAMA]. Licença de Operaçăo nº 1097/2012. Brasília, 2012a.

INSTITUTOBRASILEIRODOMEIOAMBIENTEEDOSRECURSOSNATURAISRENOVÁVEIS [IBAMA]. 1ª Retificaçăo da Licença de Operaçăo nº 1097/2012. Brasília, 2012b.

INSTITUTOBRASILEIRODOMEIOAMBIENTEEDOSRECURSOSNATURAISRENOVÁVEIS [IBAMA]. $2^{\text {a }}$ Retificaçăo da Licença de Operaçăo nº 1097/2012. Brasília, 2013.

INSTITUTO BRASILEIRO DO MEIO AMBIENTE E DOS RECURSOS NATURAIS RENOVÁVEIS [IBAMA]. Licença de Operaçăo nº 1044/2011. Brasília, 2011.

INSTITUTO BRASILEIRO DO MEIO AMBIENTE E DOS RECURSOS NATURAIS RENOVÁVEIS [IBAMA]. Licença de Operaçăo n 1044/2011 - $1^{\text {a }}$ Renovaçăo. Brasília, 2016.

INSTITUTO SOCIOAMBIENTAL [ISA]. Governo Temer articula reduzir Unidades de Conservaçăo sem consultar Meio Ambiente. 2017. Disponível em: <https://www.socioambiental.org/pt-br/noticias-socioambientais/governo-temer-articula-reduzir-unidades-de-conservacao-sem-consultar-meio-ambiente>. Acesso em: 16 fev. 2017.

LEME ENGENHARIA LTDA. Estudo de Impacto Ambiental (EIA) dos Aproveitamentos Hidrelétricos Santo Antônio e Jirau. FURNAS Centrais Elétricas S.A, Construtora Noberto Odebrecht, S.A. \& Leme Engenharia. Rio de Janeiro, 2005a.

LEME ENGENHARIA LTDA. Relatório de Impacto Ambiental (RIMA) das Usinas Hidrelétricas de Santo Antônio e Jirau. FURNAS Centrais Elétricas S.A, Construtora Norberto Odebrecht S.A. \& Leme Engenharia Ltda. Rio de Janeiro, 2005b.

LEMOS, Chélen Fischer de. 0 processo sociotécnico de eletrificaçăo na Amazônia: articulaçôes e contradiçōes entre Estado, capital e território (1890 a 1990). Tese (Doutorado em Planejamento Urbano e Regional). - Universidade Federal do Rio de Janeiro, Rio de Janeiro, 2007.

LEROY, Jean Pierre; MALERBA, Julianna (orgs.). IIRSA, energia e mineraçăo: ameaças e conflitos para as terras indígenas na Amazônia brasileira. Rio de Janeiro: FASE, 2010.

MAGGI, Leonardo Bauer. Contribuiçôes de Itaipu no processo de integraçăo elétrica regional. Dissertaçăo (Mestrado em Geografia) - Faculdade de Ciências e Tecnologia, Universidade Estadual Paulista, Presidente Prudente, 2013. Disponível em http://www2. fct.unesp.br/pos/geo/dis_teses/13/ms/leonardo.pdf. Acesso em 15 de fevereiro de 2016.

MARTINS, Renato Domingues Fialho. $\mathbf{O}$ setor elétrico pós-privatizaçăo: novas configuraçôes institucionais e espaciais. 2009. Dissertaçâo (Mestrado em Planejamento Urbano e Regional) - Universidade Federal do Rio de Janeiro, Rio de Janeiro, 2009. 
MINISTÉRIO DE MINAS E ENERGIA [MME] (Brasil). Empresa de Pesquisa Energética EPE. Plano decenal de expansâo de energia 2024. Brasília: MME/EPE, 2015.

MINISTÉRIO DE MINAS E ENERGIA [MME] (Brasil). Empresa de Pesquisa Energética EPE. Plano decenal de expansăo de energia 2027. Brasília: MME/EPE, 2017.

MINISTÉRIO DE MINAS E ENERGIA [MME] (Brasil). Contrato de concessăo $\mathbf{n}^{0}$ 001/2008-MME-UHE Santo Antônio. Processo n 48500.001273/2008-22. Brasília: MME, 2008

MINISTÉRIO DE MINAS E ENERGIA [MME] (Brasil). Secretaria de Planejamento e Desenvolvimento Energético. Ofício n 042/2007/SPE/MME. Brasília, 2007.

MINISTÉRIO DE MINAS E ENERGIA [MME] (Brasil). Gabinete do Ministro. Aviso n 295/ GM/MME. Brasília, 2005.

MINISTÉRIO DE MINAS E ENERGIA [MME] (Brasil). Empresa de Pesquisa Energética - EPE. Balanço Energético Nacional 2016. Relatório Síntese - ano base 2015. Rio de Janeiro: MME/EPE, jun. 2016.

MINISTÉRIO PÚBLICO FEDERAL [MPF]. Termo de Ajustamento de Conduta - Usina Hidrelétrica Santo Antônio. Inquérito Civil Público $n^{0}$ 1.31.000.000054/2009-90. Objetivo: Apurar eventual responsabilidade civil do Consórcio Santo Antônio Energia S/A pela morte de 11 toneladas de peixes no Rio Madeira em dezembro de 2008. Porto Velho, 04 de fevereiro de 2010.

MONTEIRO, Telma. As hidrelétricas do Madeira: as liçóes năo aprendidas que se repetem em Belo Monte. Observatório dos Investimentos na Amazônia. Brasília: Instituto de Estudos Socioeconômicos (Inesc), 2011.

OLIVEIRA JUNIOR, Joaner Campello de; VAZ, Natália Carolina de Oliveira. Os projetos de infraestrutura da IIRSA e a violaçăo dos direitos indígenas. Aracê - Direitos Humanos em Revista. Ano 4, n. 5, fev. 2017.

PINHEIRO, Daniele de Carvalho. Reestruturaçăo do setor elétrico no Brasil e suas consequências no tratamento de questōes sociais e ambientais: o caso da Usina Hidrelétrica de Cana Brava, GO. Dissertaçăo (Mestrado em Planejamento Urbano e Regional) - Universidade Federal do Rio de Janeiro, Rio de Janeiro, 2006.

PLATAFORMA DHESCA BRASIL. Relatoria Nacional para o Direito Humano ao Meio Ambiente. Violaçōes de direitos humanos ambientais no Complexo Madeira. Săo Paulo: Plataforma DhESCA Brasil, 2008.

ROSA, Luiz Pinguelli. Energia nos governos Lula e Dilma - perspectivas. Revista USP, Săo Paulo, n. 104, p.45-50, jan./fev./mar. 2015. Disponível em: <www.revistas.usp.br/revusp/ article/download/106752/105391>. Acesso em: 16 fev. 2017.

SANTO ANTONIO ENERGIA [SAE]. Acionistas. Disponível em: <http://www.santoantonioenergia.com.br/empresa/acionistas/>. Acesso em: 16 fev. 2017. 
SEVÁ Filho, Arsênio Oswaldo; GARZON, Luís Fernando Novoa \& NÓBREGA, Renata da Silva. "Rios de Rondônia: jazidas de megawatts e passivo social e ambiental" pp. 51-67. In BORRERO, Antônio Manuel Valdés \& MIGUEL, Vinicius Valentin Raduan (orgs.). Horizontes Amazônicos: economia e desenvolvimento. Rio de Janeiro: Letra Capital, 2011. ISBN: 978-85-7785-114-0

SOUZA, Fabiano Farias de. Conjuntura política e econômica no Brasil (1950-1964): terreno fértil para o golpe de 1964. Revista História e Cultura, v. 2, p. 189-204, 2013.

SVAMPA, Maristella. Extrativismo neodesenvolvimentista e movimentos sociais: um giro ecoterritorial rumo a novas alternativas? Em: DILGER, Gerhard; LANG, Miriam; PEREIRA FILHO, Jorge (orgs.). Descolonizar o imaginário: debates sobre o pós-extrativismo e alternativas ao desenvolvimento. Traduzido por Igor Ojeda. Sáo Paulo: Fundaçăo Rosa Luxemburgo, 2016.

VAINER, Carlos Bernardo. Recursos hidráulicos: questôes sociais e ambientais. Estudos Avançados, Sáo Paulo, v. 21, n. 59, p.119-137, jan./abr. 2007. Disponível em: <http://www. scielo.br/pdf/ea/v21n59/a09v2159.pdf>. Acesso em: 16 fev. 2017.

et. al. Burguesia, Estado e desenvolvimento capitalista no Brasil a partir de 1930: interpretaçôes e debates. PRACS: Revista Eletrônica de Humanidades do Curso de Ciências Sociais da UNIFAP, Macapá, v. 8, n. 2, p.51-86, jul./dez. 2015. Disponível em: <https://periodicos.unifap.br/index.php/pracs/article/view/2065〉. Acesso em: 16 fev. 2017. 